\title{
LEVEL II SCOUR ANALYSIS FOR BRIDGE 10 (HANCTH00010010) on TOWN HIGHWAY 1, crossing the WHITE RIVER, HANCOCK, VERMONT
}

U.S. Geological Survey Open-File Report 96-570

Prepared in cooperation with

VERMONT AGENCY OF TRANSPORTATION and

FEDERAL HIGHWAY ADMINISTRATION 


\section{LEVEL II SCOUR ANALYSIS FOR BRIDGE 10 (HANCTH00010010) on TOWN HIGHWAY 1, crossing the WHITE RIVER, HANCOCK, VERMONT}

By SCOTT A. OLSON and MICHAEL A. IVANOFF

U.S. Geological Survey Open-File Report 96-570

Prepared in cooperation with

VERMONT AGENCY OF TRANSPORTATION and

FEDERAL HIGHWAY ADMINISTRATION 


\title{
U.S. DEPARTMENT OF THE INTERIOR BRUCE BABBITT, Secretary
}

\author{
U.S. GEOLOGICAL SURVEY \\ Gordon P. Eaton, Director
}

For additional information write to:

District Chief

U.S. Geological Survey 361 Commerce Way

Pembroke, NH 03275-3718
Copies of this report may be purchased from:

U.S. Geological Survey

Branch of Information Services

Open-File Reports Unit

Box 25286

Denver, CO 80225-0286 


\section{CONTENTS}

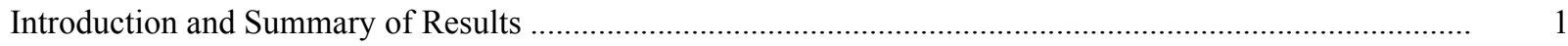

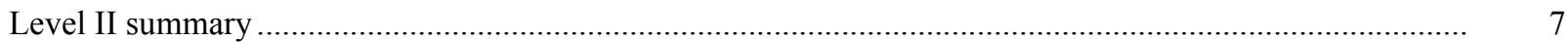

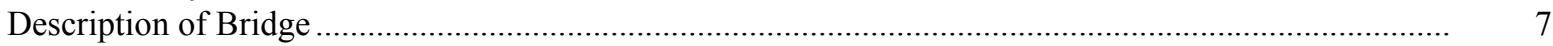

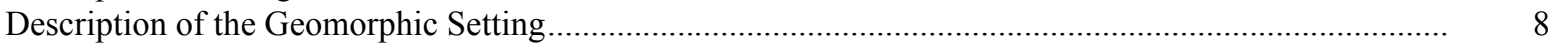

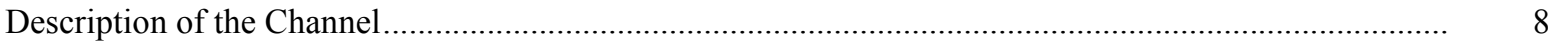

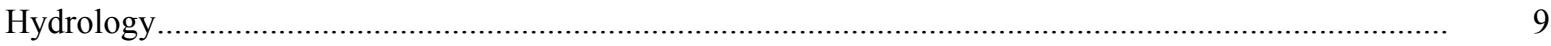

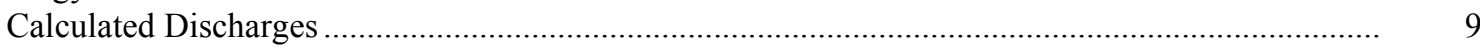

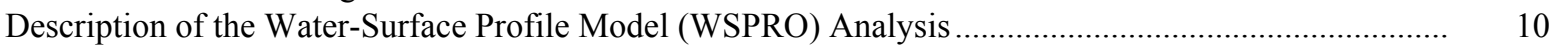

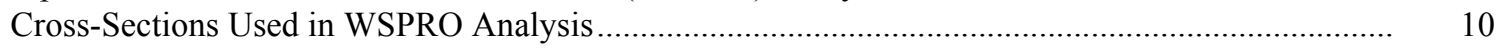

Data and Assumptions Used in WSPRO Model ...................................................................... 11

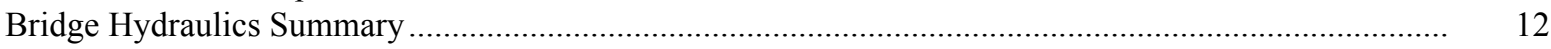

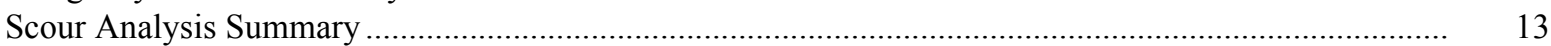

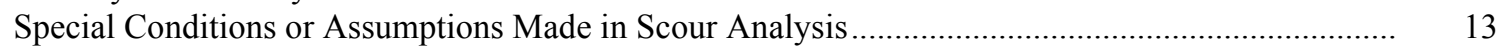

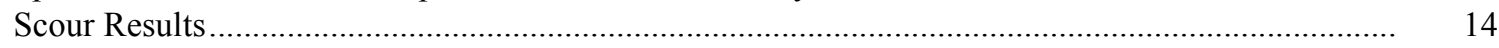

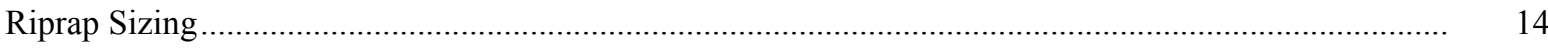

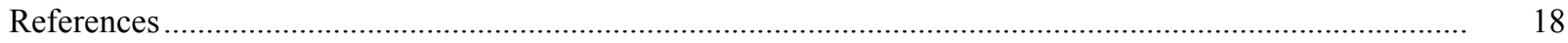

Appendixes:

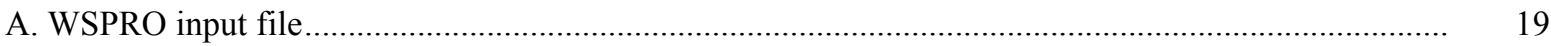

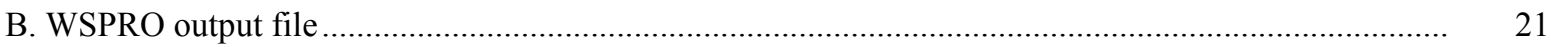

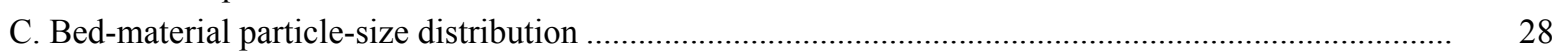

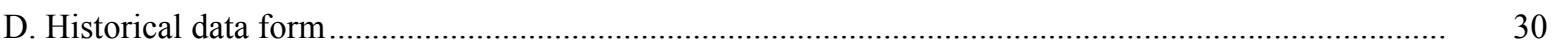

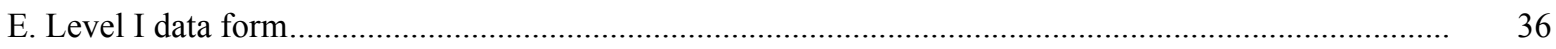

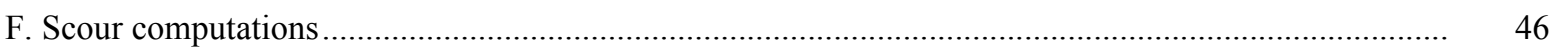

\section{FIGURES}

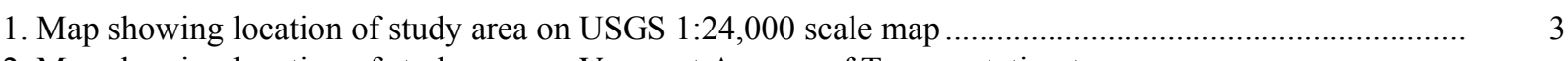

2. Map showing location of study area on Vermont Agency of Transportation town

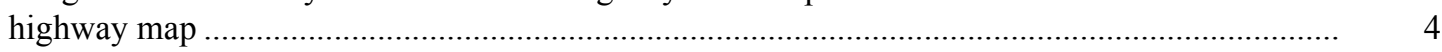

3. Structure HANCTH00010010 viewed from upstream (November 15, 1994) ......................................... 5

4. Downstream channel viewed from structure HANCTH00010010 (November 15, 1994)...................... 5

5. Upstream channel viewed from structure HANCTH00010010 (November 15, 1994) ................................. 6

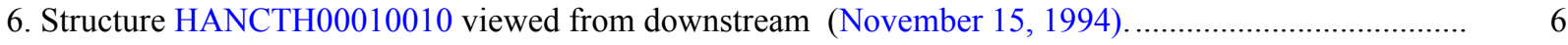

7. Water-surface profiles for the 100- and 500-year discharges at structure

HANCTH00010010 on Town Highway 1, crossing the White River,

Hancock, Vermont......

8. Scour elevations for the 100- and 500-year discharges at structure

HANCTH00010010 on Town Highway 1, crossing the White River,

Hancock, Vermont.

\section{TABLES}

1. Remaining footing/pile depth at abutments for the 100-year discharge at structure

HANCTH00010010 on Town Highway 1, crossing the White River,

Hancock, Vermont

2. Remaining footing/pile depth at abutments for the 500-year discharge at structure

HANCTH00010010 on Town Highway 1, crossing the White River,

Hancock, Vermont 


\begin{tabular}{|c|c|c|}
\hline Multiply & By & To obtain \\
\hline \multicolumn{3}{|c|}{ Length } \\
\hline inch (in.) & 25.4 & millimeter (mm) \\
\hline foot $(\mathrm{ft})$ & 0.3048 & $\operatorname{meter}(\mathrm{m})$ \\
\hline mile (mi) & 1.609 & kilometer (km) \\
\hline \multicolumn{3}{|c|}{ Slope } \\
\hline foot per mile ( $\mathrm{ft} / \mathrm{mi})$ & 0.1894 & meter per kilometer $(\mathrm{m} / \mathrm{km})$ \\
\hline \multicolumn{3}{|c|}{ Area } \\
\hline square mile $\left(\mathrm{mi}^{2}\right)$ & 2.590 & square kilometer $\left(\mathrm{km}^{2}\right)$ \\
\hline \multicolumn{3}{|c|}{ Volume } \\
\hline cubic foot $\left(\mathrm{ft}^{3}\right)$ & $\begin{array}{l}0.02832 \\
\text { Velocity and Flow }\end{array}$ & cubic meter $\left(\mathrm{m}^{3}\right)$ \\
\hline foot per second $(\mathrm{ft} / \mathrm{s})$ & 0.3048 & meter per second $(\mathrm{m} / \mathrm{s})$ \\
\hline cubic foot per second $\left(\mathrm{ft}^{3} / \mathrm{s}\right)$ & 0.02832 & cubic meter per second $\left(\mathrm{m}^{3} / \mathrm{s}\right)$ \\
\hline $\begin{array}{l}\text { cubic foot per second per } \\
\text { square mile } \\
{\left[\left(\mathrm{ft}^{3} / \mathrm{s}\right) / \mathrm{mi}^{2}\right]}\end{array}$ & 0.01093 & $\begin{array}{l}\text { cubic meter per } \\
\text { second per square } \\
\text { kilometer }\left[\left(\mathrm{m}^{3} / \mathrm{s}\right) / \mathrm{km}^{2}\right]\end{array}$ \\
\hline
\end{tabular}

OTHER ABBREVIATIONS

$\begin{array}{lrlr}\mathrm{BF} & \text { bank full } & \text { LWW } & \text { left wingwall } \\ \mathrm{cfs} & \text { cubic feet per second } & \text { MC } & \text { main channel } \\ \mathrm{D}_{50} & \text { median diameter of bed material } & \text { RAB } & \text { right abutment } \\ \mathrm{DS} & \text { downstream } & \text { RABUT } & \text { face of right abutment } \\ \mathrm{elev} & \text { elevation } & \text { RB } & \text { right bank } \\ \mathrm{f} / \mathrm{p} & \text { flood plain } & \text { ROB } & \text { right overbank } \\ \mathrm{ft} & \text { square feet } & \text { RWW } & \text { right wingwall } \\ \mathrm{ft} / \mathrm{ft} & \text { feet per foot } & \text { TH } & \text { town highway } \\ \mathrm{JCT} & \text { junction } & \text { UB } & \text { under bridge } \\ \mathrm{LAB} & \text { left abutment } & \text { US } & \text { upstream } \\ \mathrm{LABUT} & \text { face of left abutment } & \text { USGS } & \text { United States Geological Survey } \\ \text { LB } & \text { left bank } & \text { VTAOT Vermont Agency of Transportation } \\ \text { LOB } & \text { left overbank } & \text { WSPRO } & \text { water-surface profile model }\end{array}$

In this report, the words "right" and "left" refer to directions that would be reported by an observer facing downstream. Sea level: In this report, "sea level" refers to the National Geodetic Vertical Datum of 1929-- a geodetic datum derived from a general adjustment of the first-order level nets of the United States and Canada, formerly called Sea Level Datum of 1929.

In the appendices, the above abbreviations may be combined. For example, USLB would represent upstream left bank. 


\title{
LEVEL II SCOUR ANALYSIS FOR BRIDGE 10 (HANCTH00010010) ON TOWN HIGHWAY 1, CROSSING THE WHITE RIVER, HANCOCK, VERMONT
}

\author{
By Scott A. Olson and Michael A. Ivanoff
}

\section{INTRODUCTION AND SUMMARY OF RESULTS}

This report provides the results of a detailed Level II analysis of scour potential at structure HANCTH00010010 on town highway 1 crossing the White River, Hancock, Vermont (figures 1-8). A Level II study is a basic engineering analysis of the site, including a quantitative analysis of stream stability and scour (U.S. Department of Transportation, 1993). Results of a Level I scour investigation also are included in Appendix E of this report. A Level I investigation provides a qualitative geomorphic characterization of the study site. Information on the bridge, gleaned from Vermont Agency of Transportation (VTAOT) files, was compiled prior to conducting Level I and Level II analyses and is found in Appendix D.

The site is in the Green Mountain section of the New England physiographic province of central Vermont. The $59.8-\mathrm{mi}^{2}$ drainage area is in a predominantly rural and forested basin. In the vicinity of the study site, the surface cover is primarily grass with trees and brush on the immediate channel banks.

In the study area, the White River has a sinuous channel with a slope of approximately $0.005 \mathrm{ft} / \mathrm{ft}$, an average channel top width of $104 \mathrm{ft}$ and an average channel depth of $6 \mathrm{ft}$. The predominant channel bed materials are gravel and cobble with a median grain size $\left(\mathrm{D}_{50}\right)$ of $98.9 \mathrm{~mm}(0.325 \mathrm{ft})$. The geomorphic assessment at the time of the Level I and Level II site visit on November 15, 1994, indicated that the reach was stable.

The town highway 1 crossing of the White River is a 91-ft-long, two-lane bridge consisting of one 89-foot steel-beam span (Vermont Agency of Transportation, written communication, August 26,1994). The bridge is supported by vertical, concrete abutments with wingwalls. The channel is skewed approximately 15 degrees to the opening while the opening-skew-to-roadway is 0 degrees. Additional details describing conditions at the site are included in the Level II Summary and Appendices D and E. 
Scour depths and rock rip-rap sizes were computed using the general guidelines described in Hydraulic Engineering Circular 18 (Richardson and others, 1995). Total scour at a highway crossing is comprised of three components: 1) long-term streambed degradation; 2) contraction scour (due to accelerated flow caused by a reduction in flow area at a bridge) and; 3) local scour (caused by accelerated flow around piers and abutments). Total scour is the sum of the three components. Equations are available to compute depths for contraction and local scour and a summary of the results of these computations follows.

Contraction scour for all modelled flows was 0.0 feet. Abutment scour ranged from 13.1 to $17.1 \mathrm{ft}$. The worst-case abutment scour occurred at the 500-year discharge. Additional information on scour depths and depths to armoring are included in the section titled "Scour Results". Scoured-streambed elevations, based on the calculated scour depths, are presented in tables 1 and 2. A cross-section of the scour computed at the bridge is presented in figure 8. Scour depths were calculated assuming an infinite depth of erosive material and a homogeneous particle-size distribution.

It is generally accepted that the Froehlich equation (abutment scour) gives "excessively conservative estimates of scour depths" (Richardson and others, 1995, p. 47). Usually, computed scour depths are evaluated in combination with other information including (but not limited to) historical performance during flood events, the geomorphic stability assessment, existing scour protection measures, and the results of the hydraulic analyses. Therefore, scour depths adopted by VTAOT may differ from the computed values documented herein. 


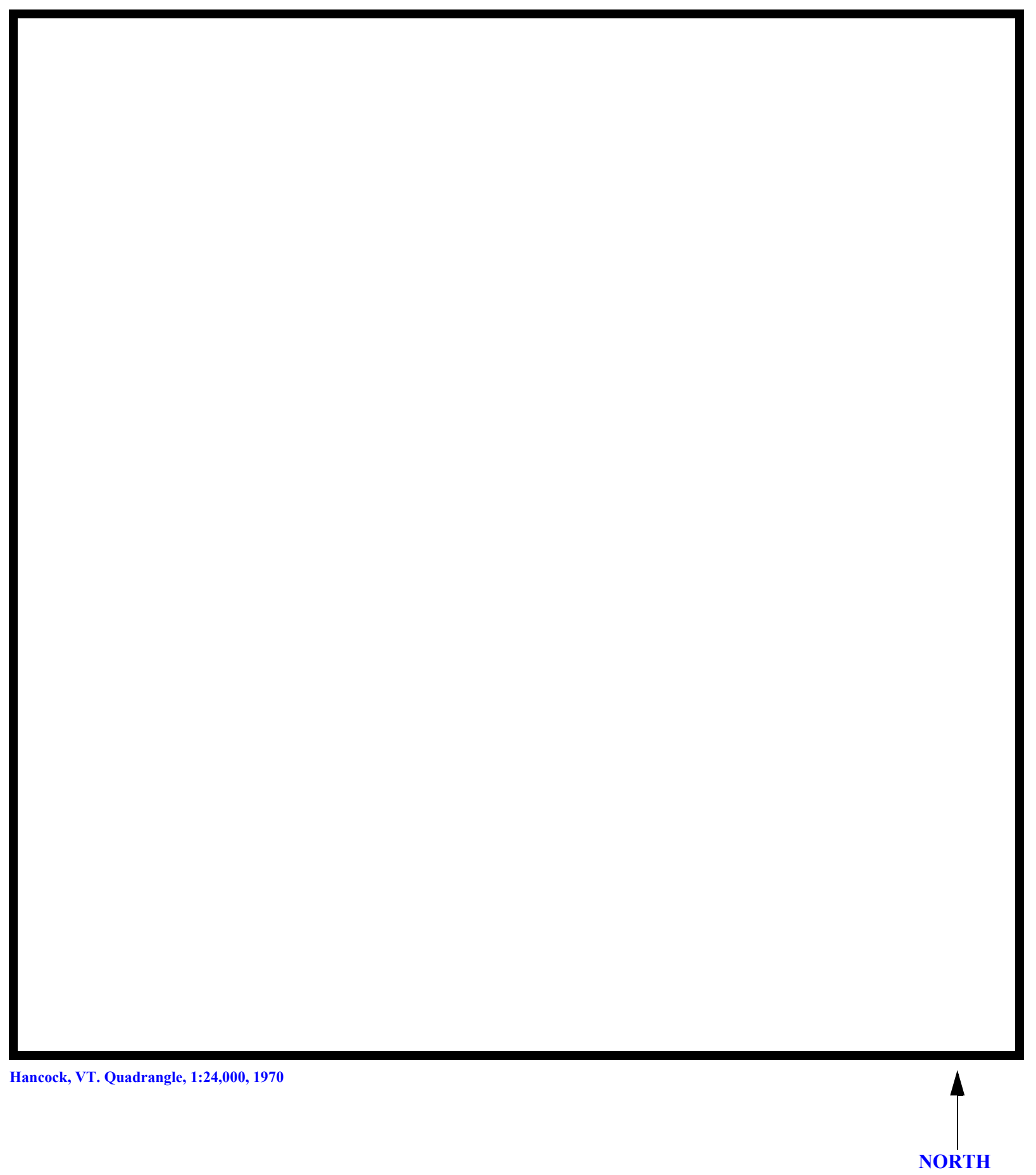

Figure 1. Location of study area on USGS 1:24,000 scale map. 
Figure 2. Location of study area on Vermont Agency of Transportation town highway map. 

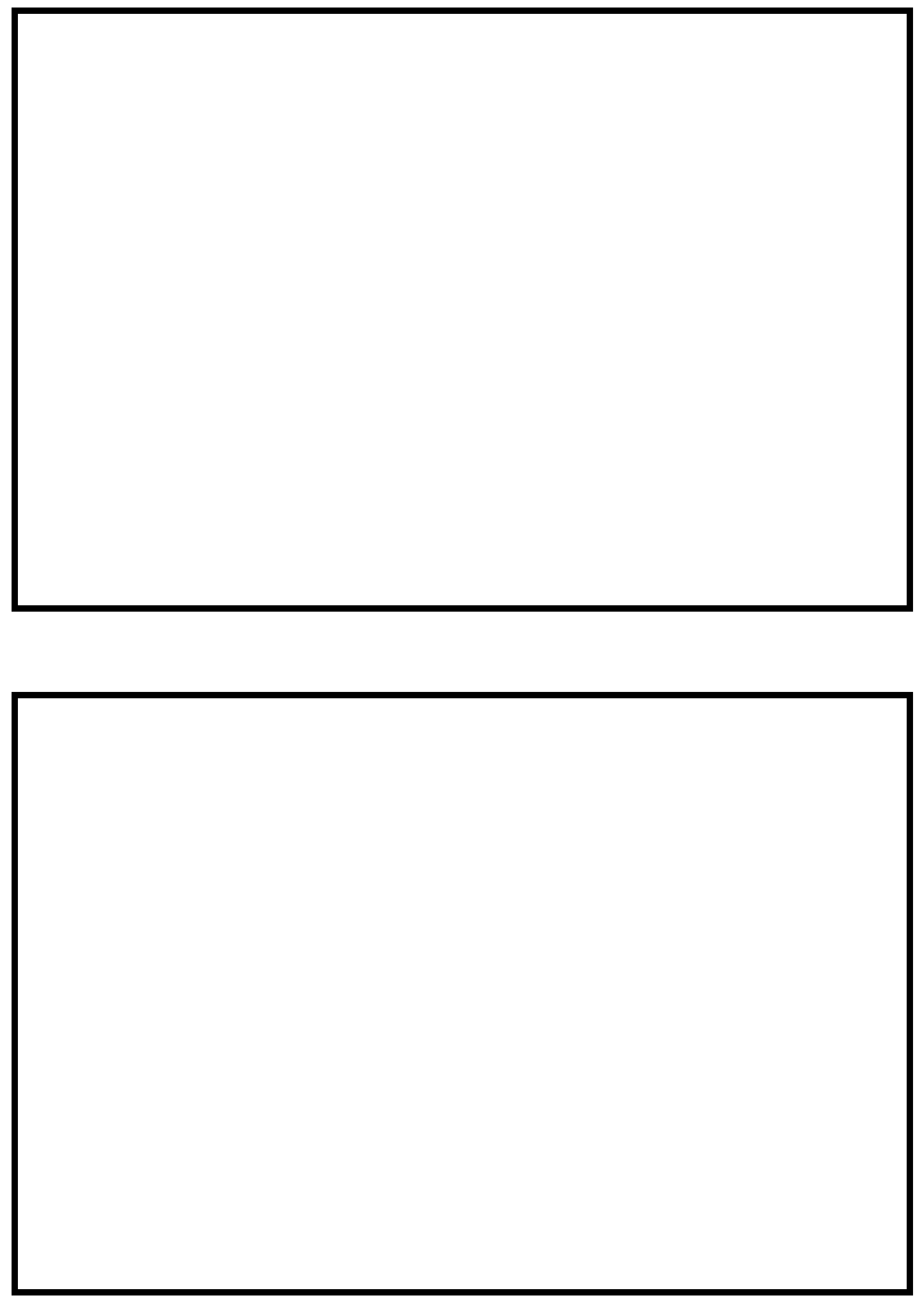

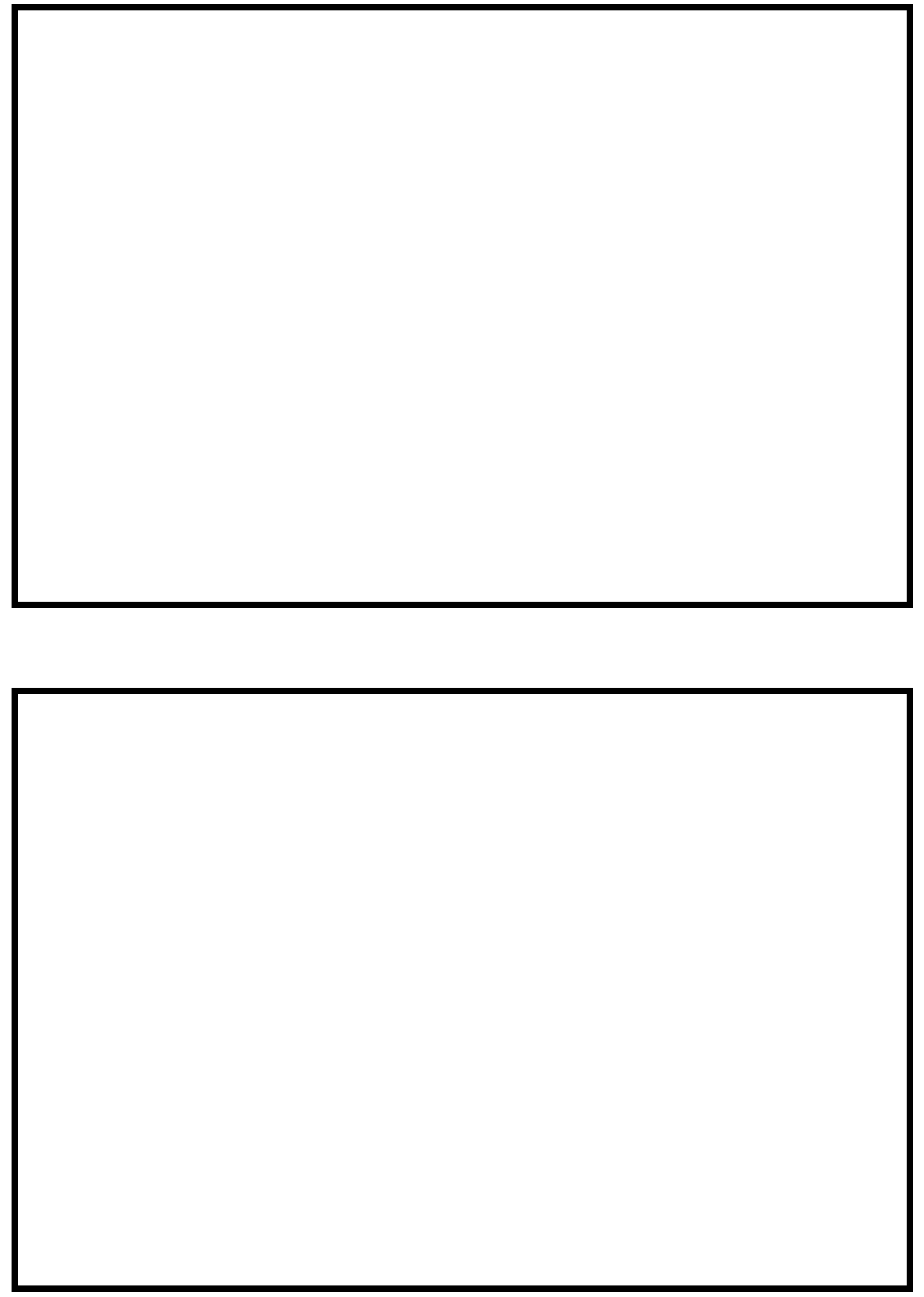


\section{LEVEL II SUMMARY}

\begin{tabular}{llllll} 
& Structure Number & HANCTH00010010 & & \multicolumn{2}{l}{ White River } \\
Stream & & & \\
County & Addison & Road & TH1 & District & 4
\end{tabular}

\section{Description of Bridge}

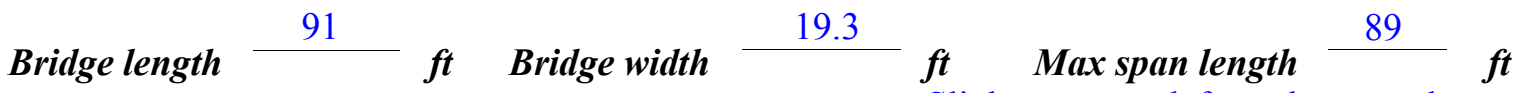
Alignment of bridge to road (on curve or straight) Vertical, concrete Abutment type Stone fill on abutment? Yes, left Embankment type Slight curve on left road approach.

\section{nommintine. af atom sil} nato af incnortion Sloping $11 / 15 / 94$ abutment and upstream left wingwall.

Abutments and wingwalls are concrete. The left abutment has an exposed footing.

\section{Y}

Is bridge skewed to flood flow according to Y Y survey? Angle

The bridge is located on a mild channel bend. The bend will cause higher flows to impact the right abutment.

Debris accumulation on bridge at time of Level I or Level II site visit:

\begin{tabular}{|c|c|c|c|}
\hline & $\begin{array}{c}\text { Date of incnortion } \\
\underline{11 / 15 / 94}\end{array}$ & $\begin{array}{l}\text { Percent of olmmus } \\
\text { blocked nortzontatly }\end{array}$ & $\begin{array}{l}\text { Percent of allone } \\
\text { blocked verticatty }\end{array}$ \\
\hline & $11 / 15 / 94$ & 0 & 0 \\
\hline & Low. & & \\
\hline
\end{tabular}

Potential for debris

Doscriho anv fonturos noar ar at tho hridoo that mav, affort flow (includo ahsorvation dato). 


\section{Description of the Geomorphic Setting}

General topography The channel is located in an approximately 1,000-foot-wide upland valley with flat to slightly irregular flood plain and steep valley walls on both sides.

Geomorphic conditions at bridge site: downstream (DS), upstream (US)

Date of inspection $\quad 11 / 15 / 94$

DS left: $\quad$ Flood plain to steep valley wall.

DS right: $\quad$ Flood plain to steep valley wall.

US left: $\quad$ Flood plain to steep valley wall.

US right: $\quad$ Flood plain to steep valley wall.

\section{Description of the Channel}

\begin{tabular}{|c|c|c|c|}
\hline \multirow[b]{2}{*}{ Average top width } & \multirow[b]{2}{*}{$\stackrel{\boldsymbol{f}}{\boldsymbol{t}}$ Gravel / Cobbles } & \multirow[b]{2}{*}{ Average depth } & \multirow{2}{*}{$\frac{6}{\text { Gravel/Cobbles }} \boldsymbol{f t}$} \\
\hline & & & \\
\hline Predominant bed material & & Bank material & Sinuous but stable \\
\hline With alluvial channel boundaries. & $\cdots$ & 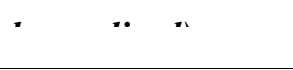 & \\
\hline
\end{tabular}

Vegetative col Grass with trees and brush on immediate channel bank.

DS left: $\quad$ Grass and paved roadway with trees and brush on immediate bank.

DS right: $\quad$ Grass with trees and brush on immediate channel bank.

US left: $\quad$ Grass and paved roadway with trees and brush on immediate bank.

US right: $\quad \underline{\mathrm{Y}}$

Do banks appear stable? --

$11 / 15 / 94$

date of observatton.

Describe any obstructions in channel and date of observation. 


\title{
Hydrology
}

Drainage area $\stackrel{59.8}{\boldsymbol{m i}^{2}}$

Percentage of drainage area in physiographic provinces: (approximate)

Physiographic province/section

New England/Green Mountain
Percent of drainage area 100

\begin{abstract}
Is drainage area considered rural or urban? Rural Describe any significant urbanization: None.
\end{abstract}

Is there a USGS gage on the stream of interest?

No

USGS gage description

USGS gage number

Gage drainage area $\mathrm{mi}^{2}$

No

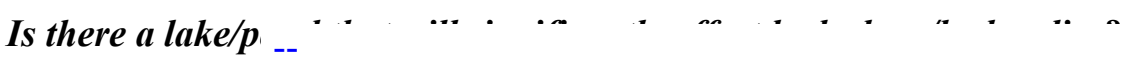

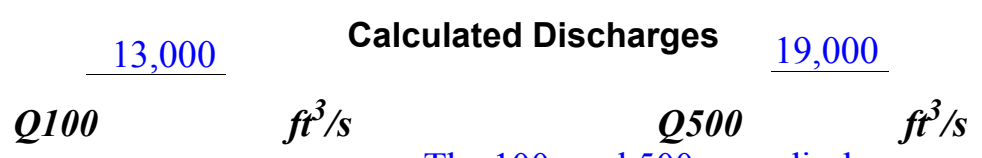

The 100- and 500-year discharges are based on a

drainage area relationship.[(59.8/56.7)exp 0.7] with a river location having flood frequency estimates in the Flood Insurance Study for the Town of Hancock (Federal Emergency Management Agency, 1991). According to the Flood Insurance Study, a site with a drainage area of 56.7 square miles on the White River has 100- and 500-year discharges of 12,500 and 18,300 cfs, respectively. 


\section{Description of the Water-Surface Profile Model (WSPRO) Analysis}

Datum for WSPRO analysis (USGS survey, sea level, VTAOT plans)

USGS survey

Datum tie between USGS survey and VTAOT plans

None

Description of reference marks used to determine USGS datum. $\quad$ RM1 is a chiseled X on

top of the downstream end of the right abutment (elev. $500.39 \mathrm{ft}$, arbitrary survey datum). RM2

is a chiseled X on top of the upstream end of the left abutment (elev. $501.36 \mathrm{ft}$, arbitrary survey

datum).

\section{Cross-Sections Used in WSPRO Analysis}

\begin{tabular}{|c|c|c|c|}
\hline${ }^{1}$ Cross-section & $\begin{array}{c}\text { Section } \\
\text { Reference } \\
\text { Distance } \\
\text { (SRD) in feet }\end{array}$ & $\begin{array}{c}{ }^{2} \text { Cross-section } \\
\text { development }\end{array}$ & Comments \\
\hline EXITX & -93 & 1 & Exit section \\
\hline FULLV & 0 & 2 & $\begin{array}{l}\text { Downstream Full-valley } \\
\text { section (Templated from } \\
\text { EXITX) }\end{array}$ \\
\hline BRIDG & 0 & 1 & Bridge section \\
\hline RDWAY & 8 & 1 & Road Grade section \\
\hline APPRO & 102 & 2 & $\begin{array}{l}\text { Modelled Approach sec- } \\
\text { tion (Templated from } \\
\text { APTEM) }\end{array}$ \\
\hline APTEM & 144 & 1 & $\begin{array}{l}\text { Approach section as sur- } \\
\text { veyed (Used as a tem- } \\
\text { plate) }\end{array}$ \\
\hline
\end{tabular}

${ }^{1}$ For location of cross-sections see plan-view sketch included with Level I field form, Appendix E.

For more detail on how cross-sections were developed see WSPRO input file. 


\section{Data and Assumptions Used in WSPRO Model}

Hydraulic analyses of the reach were done by use of the Federal Highway Administration's WSPRO step-backwater computer program (Shearman and others, 1986, and Shearman, 1990). The analyses reported herein reflect conditions existing at the site at the time of the study. Furthermore, in the development of the model it was necessary to assume no accumulation of debris or ice at the site. Results of the hydraulic model are presented in the Bridge Hydraulic Summary, Appendix B, and figure 7.

Channel roughness factors (Manning's " $n$ ") used in the hydraulic model were estimated using field inspections at each cross section following the general guidelines described by Arcement and Schneider (1989). Final adjustments to the values were made during the modelling of the reach. Channel " $\mathrm{n}$ " values for the reach ranged from 0.045 to 0.050 , and overbank " $\mathrm{n}$ " values ranged from 0.035 to 0.085 .

Normal depth at the exit section (EXITX) was assumed as the starting water surface. This depth was computed by use of the slope-conveyance method outlined in the user's manual for WSPRO (Shearman, 1990). The slope used was $0.0050 \mathrm{ft} / \mathrm{ft}$ which was measured from the 100-year water-surface profile downstream of the bridge in the Flood Insurance Study for the Town of Hancock (Federal Emergency Management Agency, 1991).

The surveyed approach section (APTEM) was moved along the approach channel slope $(0.0069 \mathrm{ft} / \mathrm{ft})$ to establish the modelled approach section (APPRO), one bridge length upstream

of the upstream face as recommended by Shearman and others (1986). This approach also provides a consistent method for determining scour variables. 


\section{Bridge Hydraulics Summary}

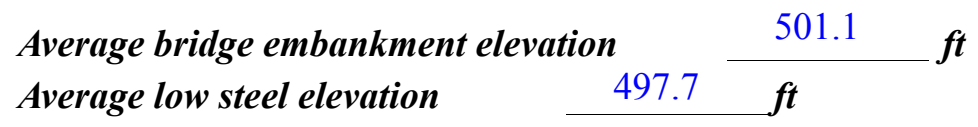

$$
\text { 100-year discharge } \quad 13,000 \quad \mathrm{ft}^{3} / \mathrm{s}
$$

Water-surface elevation in bridge opening $\quad 498.3 \quad f t$

Road overtopping? ___ Y Discharge over road _ $\quad 4,980, \%$

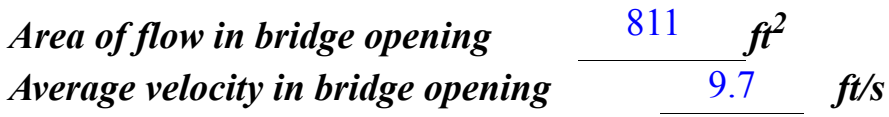

Maximum WSPRO tube velocity at bridge $11.1 \mathrm{ft} / \mathrm{s}$

Water-surface elevation at Approach section with bridge 500.8

Water-surface elevation at Approach section without bridge $\quad 499.1$

Amount of backwater caused by bridge $\quad 1.7 \quad$ it

500-year discharge $\quad 19,000 \quad \mathrm{ft}^{3} / \mathrm{s}$

Water-surface elevation in bridge opening $\quad 498.3 \mathrm{ft}$

Road overtopping? ___ Y Discharge over road _ 11,000, , s

\begin{tabular}{llll} 
Area of flow in bridge opening & 811 & $\boldsymbol{f t}^{2}$ & \\
\cline { 2 - 4 } Average velocity in bridge opening & & 9.5 & $\boldsymbol{f t} / \mathrm{s}$
\end{tabular}

Maximum WSPRO tube velocity at bridge 10.7 's

Water-surface elevation at Approach section with bridge 502.1

Water-surface elevation at Approach section without bridge $\quad 500.5$

Amount of backwater caused by bridge $\quad 1.6$.

Incipient overtopping discharge $\quad$ 7,880 $\mathrm{ft}^{3} / \mathrm{s}$

Water-surface elevation in bridge opening $496.1 \quad t$

Area of flow in bridge opening $\quad 681 \quad \mathrm{ft}^{2}$

Average velocity in bridge opening $11.6 \mathrm{ft} / \mathrm{s}$

Maximum WSPRO tube velocity at bridge $\quad 13.4 \mathrm{ft} / \mathrm{s}$

Water-surface elevation at Approach section with bridge

Water-surface elevation at Approach section without bridge

Amount of backwater caused by bridge $\quad$\begin{tabular}{ll}
0.9 \\
\hline
\end{tabular}

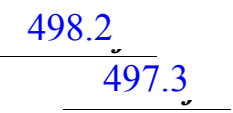




\section{Scour Analysis Summary}

\section{Special Conditions or Assumptions Made in Scour Analysis}

Scour depths were computed using the general guidelines described in Hydraulic Engineering Circular 18 (Richardson and others, 1995). Scour depths were calculated assuming an infinite depth of erosive material and a homogeneous particle-size distribution. The results of the scour analysis are presented in tables 1 and 2 and a graph of the scour depths is presented in figure 8 .

Contraction scour was computed by use of the Chang pressure-flow scour equation (Richardson and others, 1995, p. 145-146) for the 100-year and 500-year discharges, where orifice flow was present at the bridge. Contraction scour at bridges with orifice flow is best estimated by use of the Chang pressure-flow scour equation (oral communication, J. Sterling Jones, October 4, 1996). The results of Laursen's clear-water contraction scour equation (Richardson and others, 1995, p. 32, equation 20) were also computed for the 100-year and 500 -year discharges and can be found in appendix F. Contraction scour was computed by use of the Laursen's clear-water contraction scour equation for the incipient overtopping discharge. For contraction scour computations, the average depth in the contracted section (AREA/TOPWIDTH) is subtracted from the depth of flow computed by the scour equation (Y2) to determine the actual amount of scour.

Abutment scour for the right abutment was computed by use of the Froehlich equation (Richardson and others, 1995, p. 48, equation 28). Variables for the Froehlich equation include the Froude number of the flow approaching the embankments, the length of the embankment blocking flow, and the depth of flow approaching the embankment less any roadway overtopping.

Scour at the left abutment was computed by use of the HIRE equation (Richardson and others, 1995, p. 49, equation 29) because the HIRE equation is recommended when the length to depth ratio of the embankment blocking flow exceeds 25 . The variables used by the HIRE abutment-scour equation are defined the same as those defined for the Froehlich abutment-scour equation. 


\section{Scour Results}

\section{0-yr discharge 500-yr discharge}

Contraction scour:

(Scour depths in feet)

Main channel

Live-bed scour

Clear-water scour

Depth to armoring

Left overbank

Right overbank

Local scour:

Abutment scour

Left abutment

13.3

13.1

10.1

15.9

$17.1-$

13.2-

Right abutment

Pier scour

Pier 1

Pier 2

Pier 3

\section{Abutments:}

Left abutment

Right abutment

Piers:

Pier 1

Pier 2

overtopping discharge 


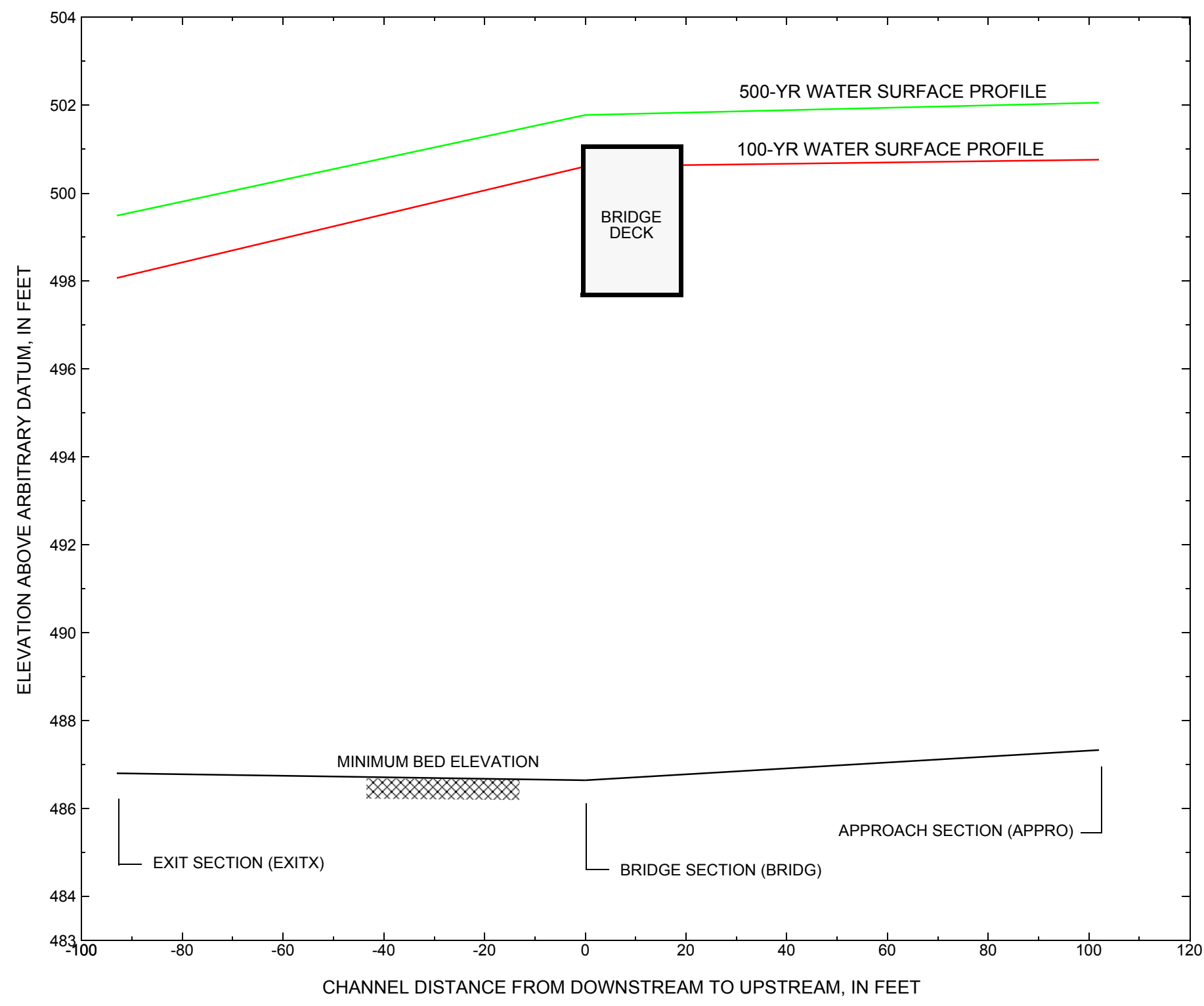

Figure 7. Water-surface profiles for the 100- and 500-yr discharges at structure HANCTH00010010 on town highway 1, crossing the White River, Hancock, Vermont. 


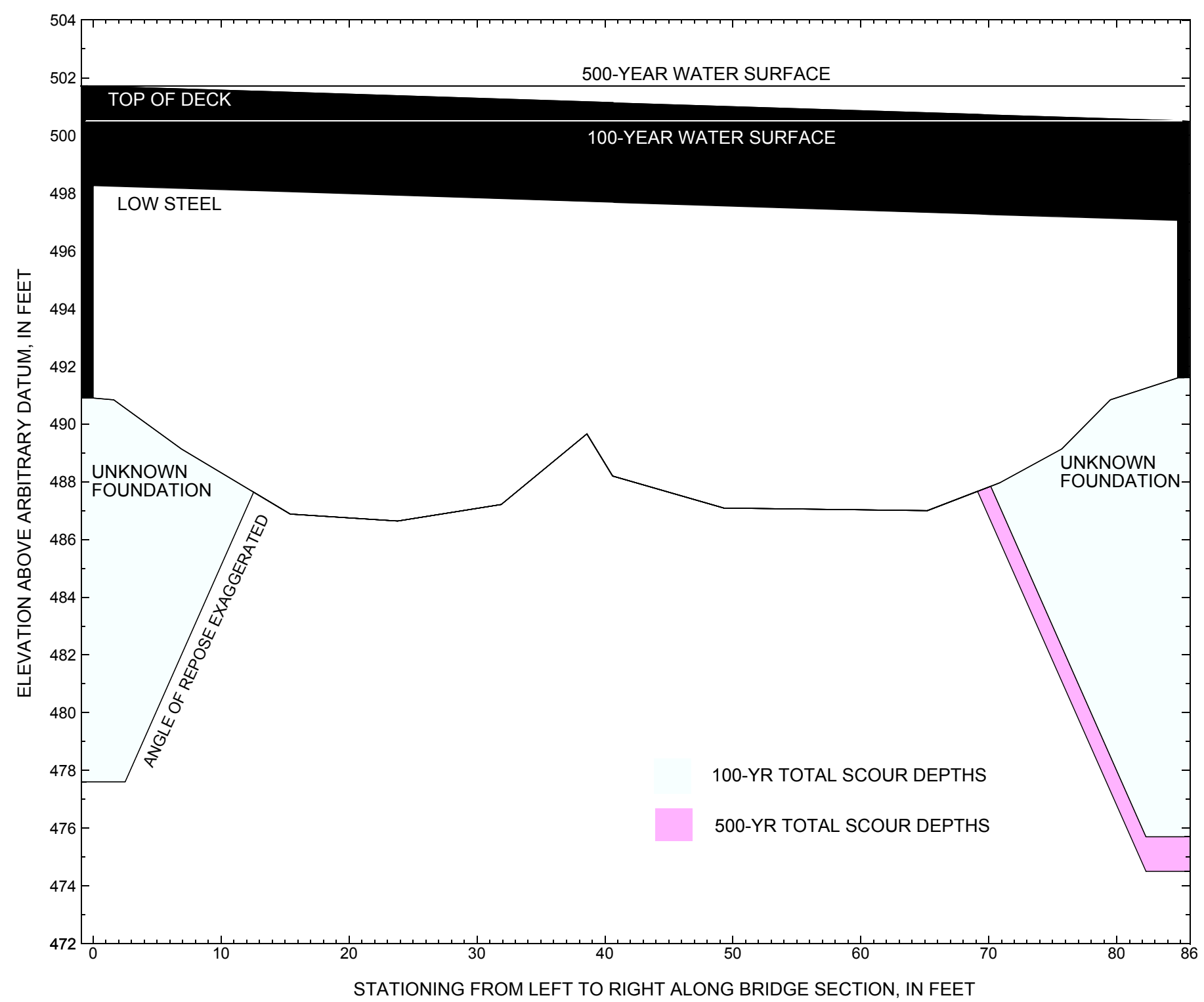

Figure 8. Scour elevations for the 100-yr and 500-yr discharges at structure HANCTH00010010 on town highway 1, crossing the White River, Hancock, Vermont. 
Table 1. Remaining footing/pile depth at abutments for the 100-year discharge at structure HANCTH00010010 on Town Highway 1, crossing the White River, Hancock, Vermont.

[VTAOT, Vermont Agency of Transportation; --,no data]

\begin{tabular}{|c|c|c|c|c|c|c|c|c|c|c|c|}
\hline Description & Station $^{1}$ & $\begin{array}{l}\text { VTAOT } \\
\text { minimum } \\
\text { low-chord } \\
\text { elevation } \\
\text { (feet) }\end{array}$ & $\begin{array}{l}\text { Surveyed } \\
\text { minimum } \\
\text { low-chord } \\
\text { elevation } \\
\text { (feet) }\end{array}$ & $\begin{array}{l}\text { Bottom of } \\
\text { footing } \\
\text { elevation } \\
\text { (feet) }\end{array}$ & $\begin{array}{c}\text { Channel } \\
\text { elevation at } \\
\text { abutment/ } \\
\text { pier }^{2} \\
\text { (feet) }\end{array}$ & $\begin{array}{l}\text { Contraction } \\
\text { scour depth } \\
\text { (feet) }\end{array}$ & $\begin{array}{l}\text { Abutment } \\
\text { scour } \\
\text { depth } \\
\text { (feet) }\end{array}$ & $\begin{array}{l}\text { Pier } \\
\text { scour } \\
\text { depth } \\
\text { (feet) }\end{array}$ & $\begin{array}{l}\text { Depth of } \\
\text { total scour } \\
\text { (feet) }\end{array}$ & $\begin{array}{l}\text { Elevation of } \\
\text { scour }^{2} \\
\text { (feet) }\end{array}$ & $\begin{array}{c}\text { Remaining } \\
\text { footing/pile } \\
\text { depth } \\
\text { (feet) }\end{array}$ \\
\hline \multicolumn{12}{|c|}{100 -yr. discharge is 13,000 cubic-feet per second } \\
\hline Left abutment & 0.0 & -- & 498.3 & -- & 490.9 & 0.0 & 13.3 & -- & 13.3 & 477.6 & -- \\
\hline Right abutment & 84.8 & -- & 497.1 & -- & 491.6 & 0.0 & 15.9 & -- & 15.9 & 475.7 & -- \\
\hline
\end{tabular}

1. Measured along the face of the most constricting side of the bridge.

2. Arbitrary datum for this study.

Table 2. Remaining footing/pile depth at abutments for the 500-year discharge at structure HANCTH00010010 on Town Highway 1, crossing the White River, Hancock, Vermont.

[VTAOT, Vermont Agency of Transportation; --, no data]

\begin{tabular}{|c|c|c|c|c|c|c|c|c|c|c|c|}
\hline Description & Station $^{1}$ & $\begin{array}{l}\text { VTAOT } \\
\text { minimum } \\
\text { low-chord } \\
\text { elevation } \\
\text { (feet) }\end{array}$ & $\begin{array}{c}\text { Surveyed } \\
\text { minimum } \\
\text { low-chord } \\
\text { elevation }{ }^{2} \\
\text { (feet) }\end{array}$ & $\begin{array}{c}\text { Bottom of } \\
\text { footing } \\
\text { elevation } \\
\text { (feet) }\end{array}$ & $\begin{array}{c}\text { Channel } \\
\text { elevation at } \\
\text { abutment/ } \\
\text { pier }^{2} \\
\text { (feet) }\end{array}$ & $\begin{array}{l}\text { Contraction } \\
\text { scour depth } \\
\text { (feet) }\end{array}$ & $\begin{array}{l}\text { Abutment } \\
\text { scour } \\
\text { depth } \\
\text { (feet) }\end{array}$ & $\begin{array}{l}\text { Pier } \\
\text { scour } \\
\text { depth } \\
\text { (feet) }\end{array}$ & $\begin{array}{l}\text { Depth of } \\
\text { total scour } \\
\text { (feet) }\end{array}$ & $\begin{array}{c}\text { Elevation of } \\
\text { scour }^{2} \\
\text { (feet) }\end{array}$ & $\begin{array}{c}\text { Remaining } \\
\text { footing/pile } \\
\text { depth } \\
\text { (feet) }\end{array}$ \\
\hline \multicolumn{12}{|c|}{500 -yr. discharge is 19,000 cubic-feet per second } \\
\hline Left abutment & 0.0 & -- & 498.3 & -- & 490.9 & 0.0 & 13.1 & -- & 13.1 & 477.8 & -- \\
\hline Right abutment & 84.8 & -- & 497.1 & -- & 491.6 & 0.0 & 17.1 & -- & 17.1 & 474.5 & -- \\
\hline
\end{tabular}

1. Measured along the face of the most constricting side of the bridge.

2. Arbitrary datum for this study. 


\section{SELECTED REFERENCES}

Arcement, G.J., Jr., and Schneider, V.R., 1989, Guide for selecting Manning's roughness coefficients for natural channels and flood plains: U.S. Geological Survey Water-Supply Paper 2339, 38 p.

Barnes, H.H., Jr., 1967, Roughness characteristics of natural channels: U.S. Geological Survey Water-Supply Paper 1849,213 p.

Benson, M. A., 1962, Factors Influencing the Occurrence of Floods in a Humid Region of Diverse Terrain: U.S. Geological Survey WaterSupply Paper 1580-B, 64 p.

Brown, S.A. and Clyde, E.S., 1989, Design of riprap revetment: Federal Highway Administration Hydraulic Engineering Circular No. 11, Publication FHWA-IP-89-016, 156 p.

Federal Highway Administration, 1983, Runoff estimates for small watersheds and development of sound design: Federal Highway Administration Report FHWA-RD-77-158

Federal Emergency Management Agency, 1991, Flood Insurance Study, Town of Hancock, Addison County, Vermont: Washington, D.C., August 19, 1991.

Froehlich, D.C., 1989, Local scour at bridge abutments in Ports, M.A., ed., Hydraulic Engineering--Proceedings of the 1989 National Conference on Hydraulic Engineering: New York, American Society of Civil Engineers, p. 13-18.

Hayes, D.C.,1993, Site selection and collection of bridge-scour data in Delaware, Maryland, and Virginia: U.S. Geological Survey WaterResources Investigation Report 93-4017, 23 p.

Interagency Advisory Committee on Water Data, 1982, Guidelines for determining flood flow frequency: U.S. Geological Survey, Bulletin 17B of the Hydrology Subcommittee, 190 p.

Johnson, C.G. and Tasker, G.D.,1974, Progress report on flood magnitude and frequency of Vermont streams: U.S. Geological Survey OpenFile Report 74-130, 37 p.

Lagasse, P.F., Schall, J.D., Johnson, F., Richardson, E.V., Chang, F., 1995, Stream Stability at Highway Structures: Federal Highway Administration Hydraulic Engineering Circular No. 20, Publication FHWA-IP-90-014, 144 p.

Laursen, E.M., 1960, Scour at bridge crossings: Journal of the Hydraulics Division, American Society of Civil Engineers, v. 86, no. HY2, p. 39-53.

Potter, W. D., 1957a, Peak rates of runoff in the Adirondack, White Mountains, and Maine woods area, Bureau of Public Roads

Potter, W. D., 1957b, Peak rates of runoff in the New England Hill and Lowland area, Bureau of Public Roads

Richardson, E.V. and Davis, S.R., 1995, Evaluating scour at bridges: Federal Highway Administration Hydraulic Engineering Circular No. 18, Publication FHWA-IP-90-017, 204 p.

Richardson, E.V., Simons, D.B., and Julien, P.Y., 1990, Highways in the river environment: Federal Highway Administration Publication FHWA-HI-90-016.

Ritter, D.F., 1984, Process Geomorphology: W.C. Brown Co., Debuque, Iowa, 603 p.

Shearman, J.O., 1990, User's manual for WSPRO--a computer model for water surface profile computations: Federal Highway Administration Publication FHWA-IP-89-027, 187 p.

Shearman, J.O., Kirby, W.H., Schneider, V.R., and Flippo, H.N., 1986, Bridge waterways analysis model; research report: Federal Highway Administration Publication FHWA-RD-86-108, 112 p.

Talbot, A.N., 1887, The determination of water-way for bridges and culverts.

U.S. Department of Transportation, 1993, Stream stability and scour at highway bridges, Participant Workbook: Federal Highway Administration Publication FHWA HI-91-011.

U.S. Geological Survey, 1970, Hancock, Vermont 7.5 Minute Series quadrangle map: U.S. Geological Survey Topographic Maps, Scale $1: 24,000$. 


\section{APPENDIX A: \\ WSPRO INPUT FILE}




\section{WSPRO INPUT FILE}

XS

GR

GR

GR

GR

GR

GR

$\mathrm{N}$

SA

XS

$\mathrm{BR}$

GR

GR

GR

GR

GR

$\mathrm{N}$

CD

*

$\mathrm{XR}$

GR

GR

GR

GR

*

$\mathrm{XT}$

GR

GR

GR

GR

GR

GR

\section{*}

AS APPRO 102

GT $\quad-0.29$

$\mathrm{N}$

SA

*

HP 1 BRIDG

HP 2 BRIDG

HP 2 RDWAY

HP 1 APPRO

HP 2 APPRO

*

HP 1 BRIDG

HP 2 BRIDG

HP 2 RDWAY

RDWAY

0.035

U.S. Geological Survey WSPRO Input File hanc010.wsp Hydraulic analysis for structure HANCO10 Hydraulic analysis of HANCO10 over the white River

$\begin{array}{lllllllllllllllllllll}6 & 29 & 30 & 552 & 553 & 551 & 5 & 16 & 17 & 13 & 3 & * & 15 & 14 & 23 & 21 & 11 & 12 & 4 & 7 & 3\end{array}$ $1300019000 \quad 7880$

$0.0050 \quad 0.0050 \quad 0.0050$

$\operatorname{EXITX}-93$

$$
\begin{array}{rrrr}
-239.4, & 507.63 & -195.2, & 493.99 \\
-20.9, & 494.87 & -6.5, & 493.72 \\
13.8, & 487.25 & 46.0, & 487.59 \\
67.0, & 487.39 & 76.5, & 489.20 \\
107.4, & 494.47 & 125.3, & 493.28 \\
194.7, & 496.41 & 464.6, & 500.53 \\
0.070 & \multicolumn{2}{c}{0.045} & 0.050 \\
& -6.5 & 94.1
\end{array}
$$

$$
\begin{aligned}
-70.3, & 494.28 \\
0.0, & 491.83 \\
54.3, & 486.80 \\
84.3, & 491.96 \\
134.6, & 497.60 \\
464.6, & 507
\end{aligned}
$$

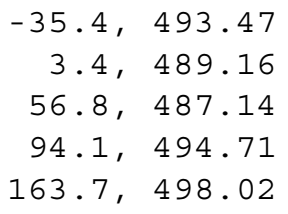

819.3

$-277.7,507.17$

$-201.4,499.93$

$-128.9,498.13$

$-62.0,499.50$

$85.6,502.13$

$85.6,500.63$

$147.0,499.01$

$175.4,498.56$

$237.5,497.89$

$464.6,500.53$

$464.6,507$

$-63.4^{0.085}-5.6$

0.050

0.075

$$
\begin{aligned}
-171.6, & 501.16 \\
-5.6, & 495.38 \\
26.9, & 487.62 \\
74.3, & 491.51 \\
153.5, & 498.29 \\
464.6, & 507
\end{aligned}
$$

$$
\begin{array}{rr}
-137.8, & 496.94 \\
0.0, & 492.27 \\
35.5, & 488.11 \\
87.5, & 494.12 \\
185.2, & 498.99
\end{array}
$$

498.271498 .27

498.27 * 7889

500.61 * * 4976

500.761500 .76

$500.76 *$ * 13000

498.271498 .27

498.27 * * 7657

501.78 * * 11031 


\section{APPENDIX B: \\ WSPRO OUTPUT FILE}


WSPRO OUTPUT FILE

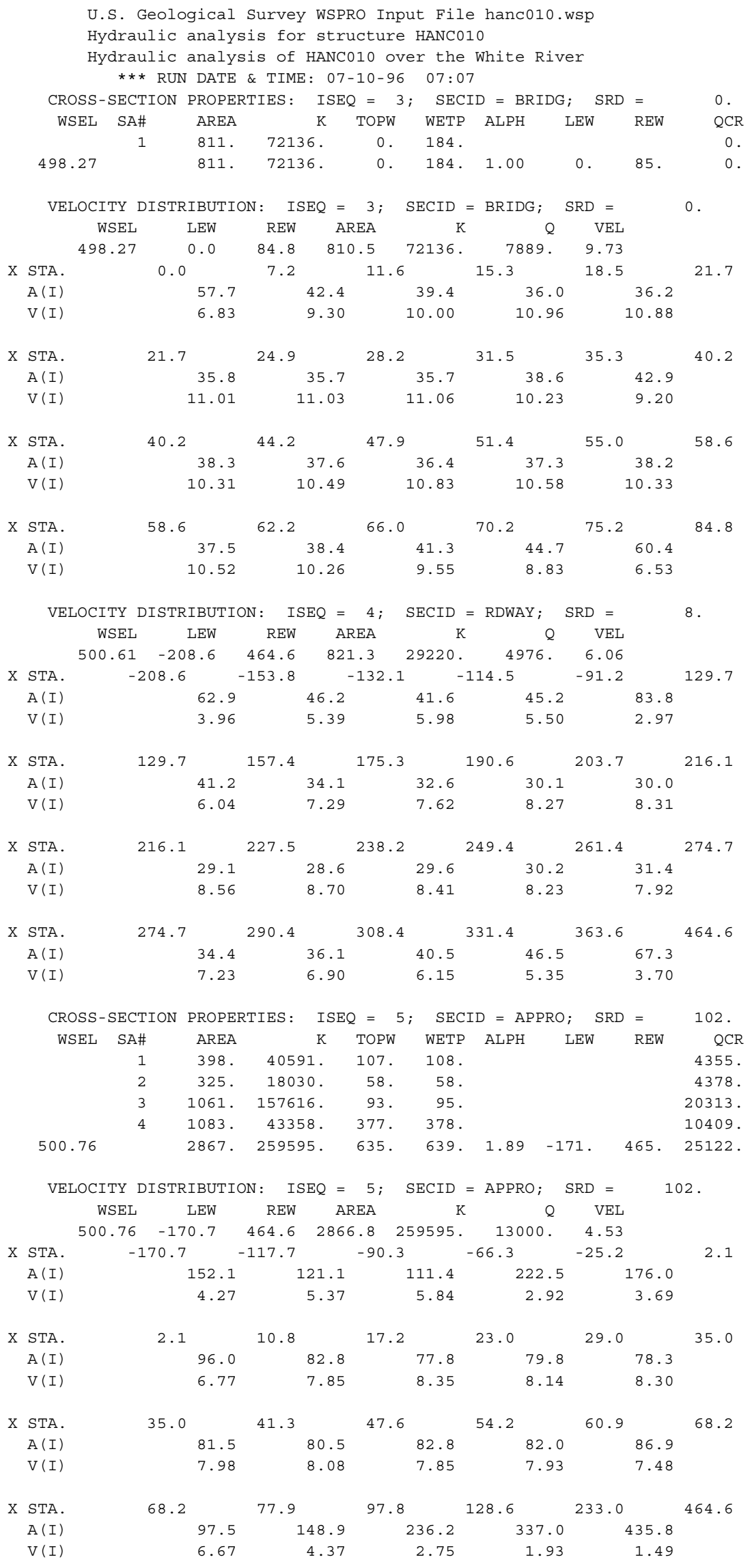


WSPRO OUTPUT FILE (continued)

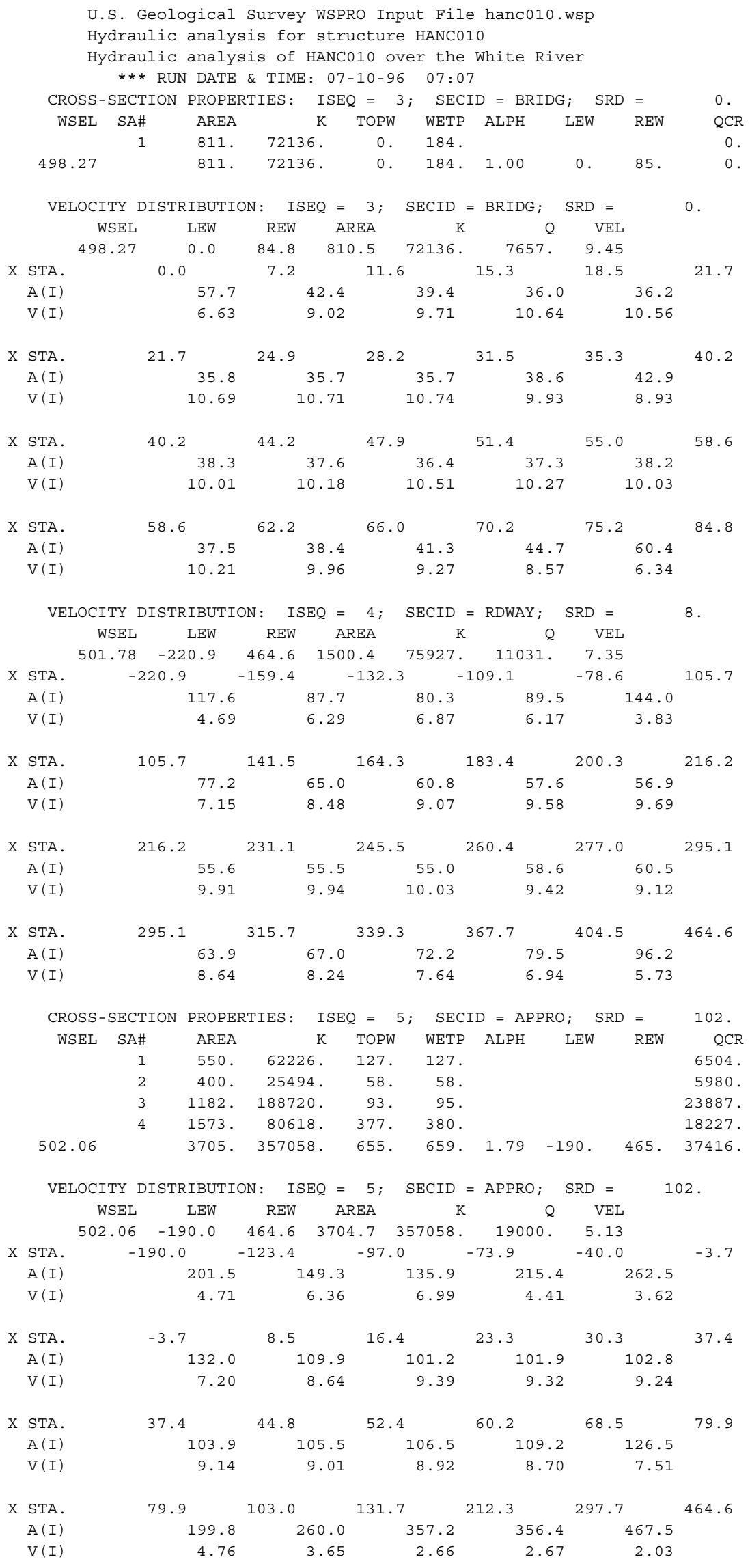


WSPRO OUTPUT FILE (continued)

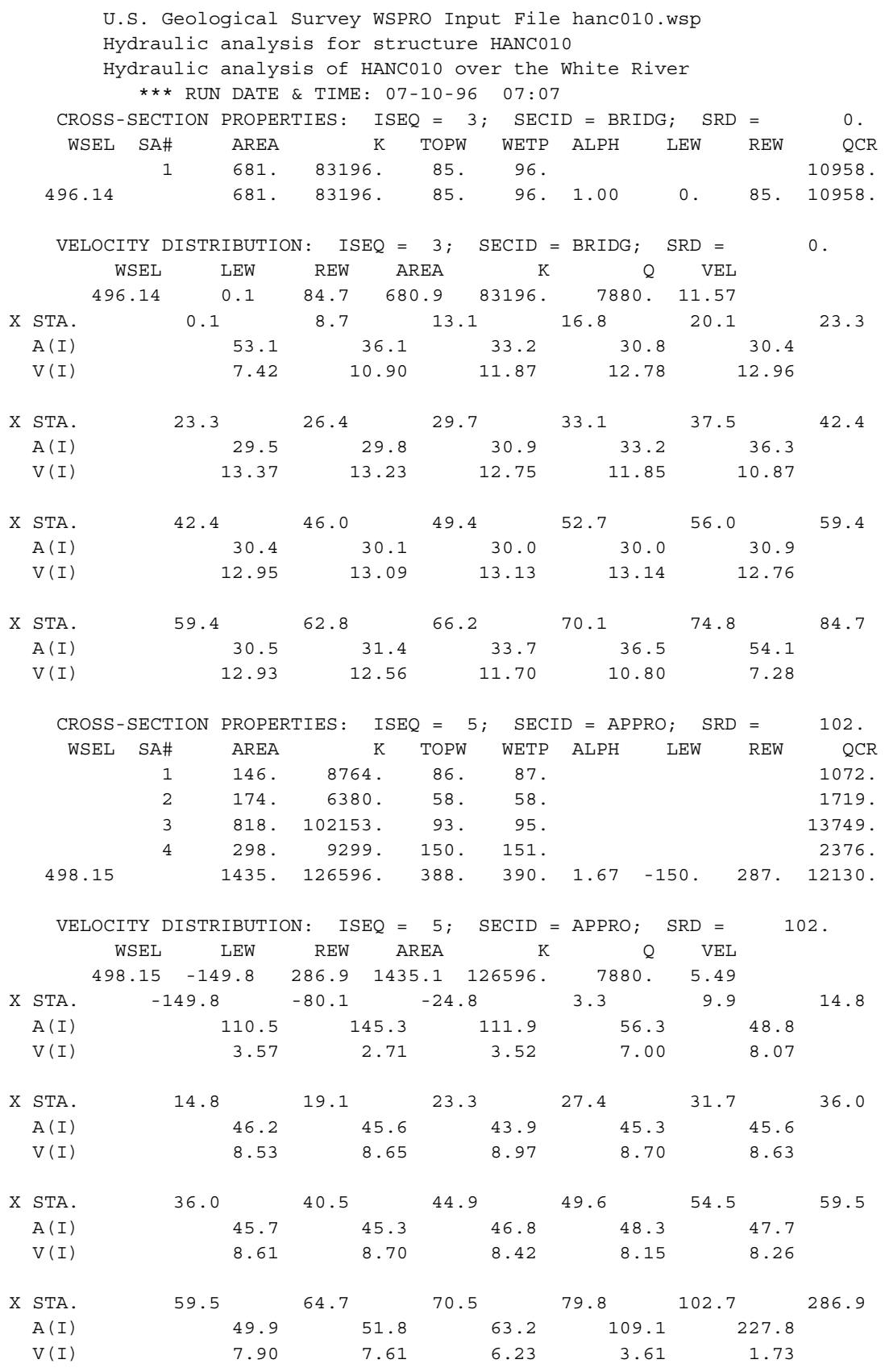


WSPRO OUTPUT FILE (continued)

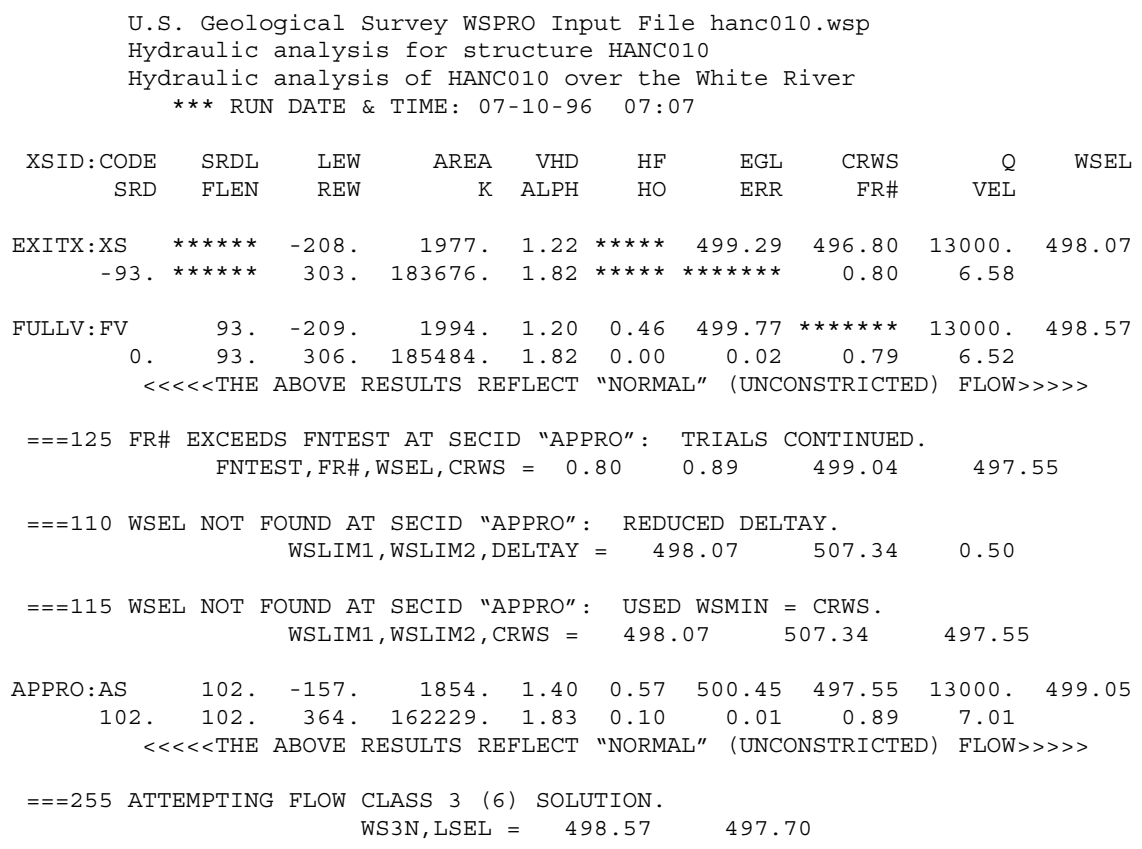


WSPRO OUTPUT FILE (continued)

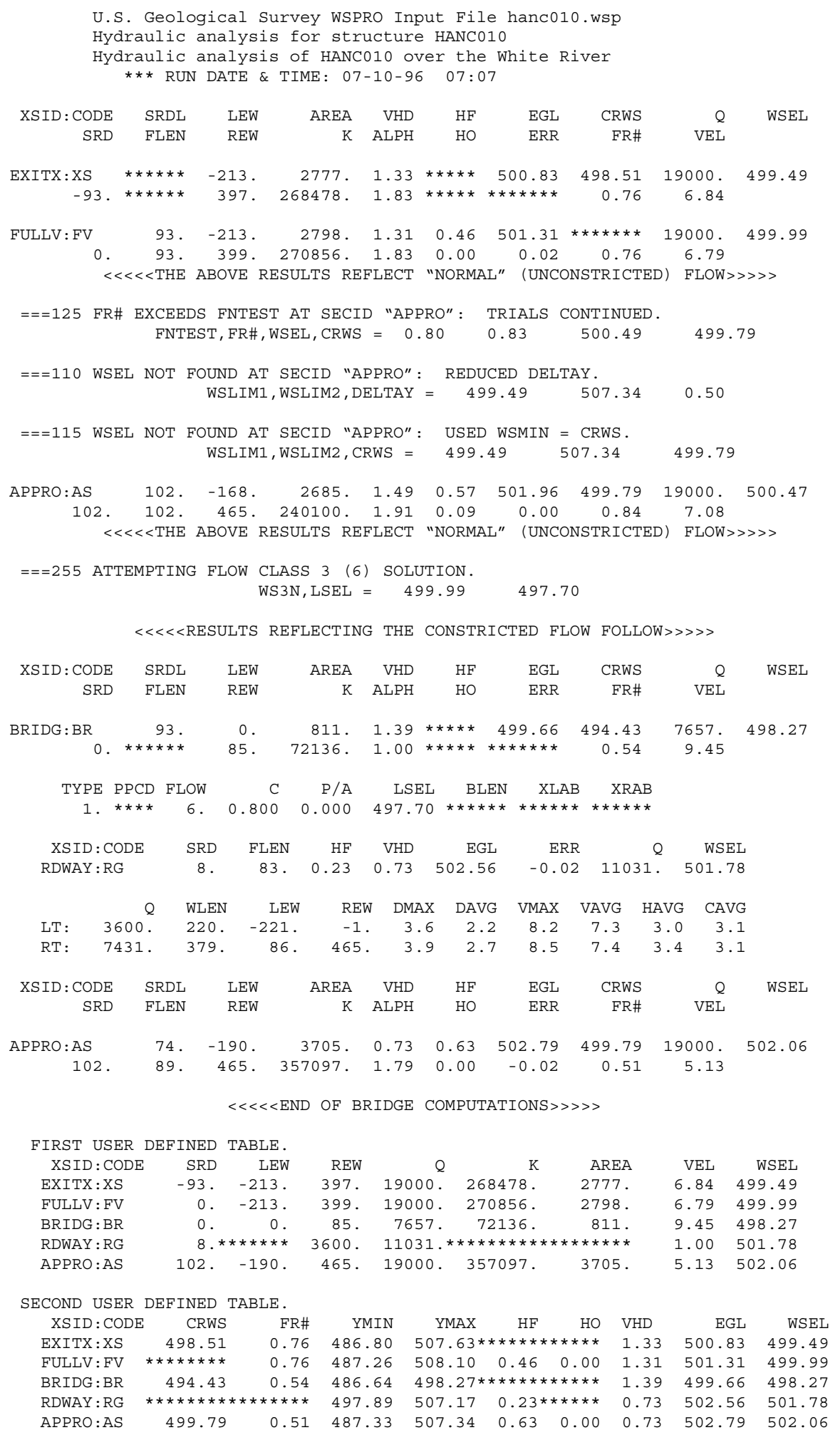


WSPRO OUTPUT FILE (continued)

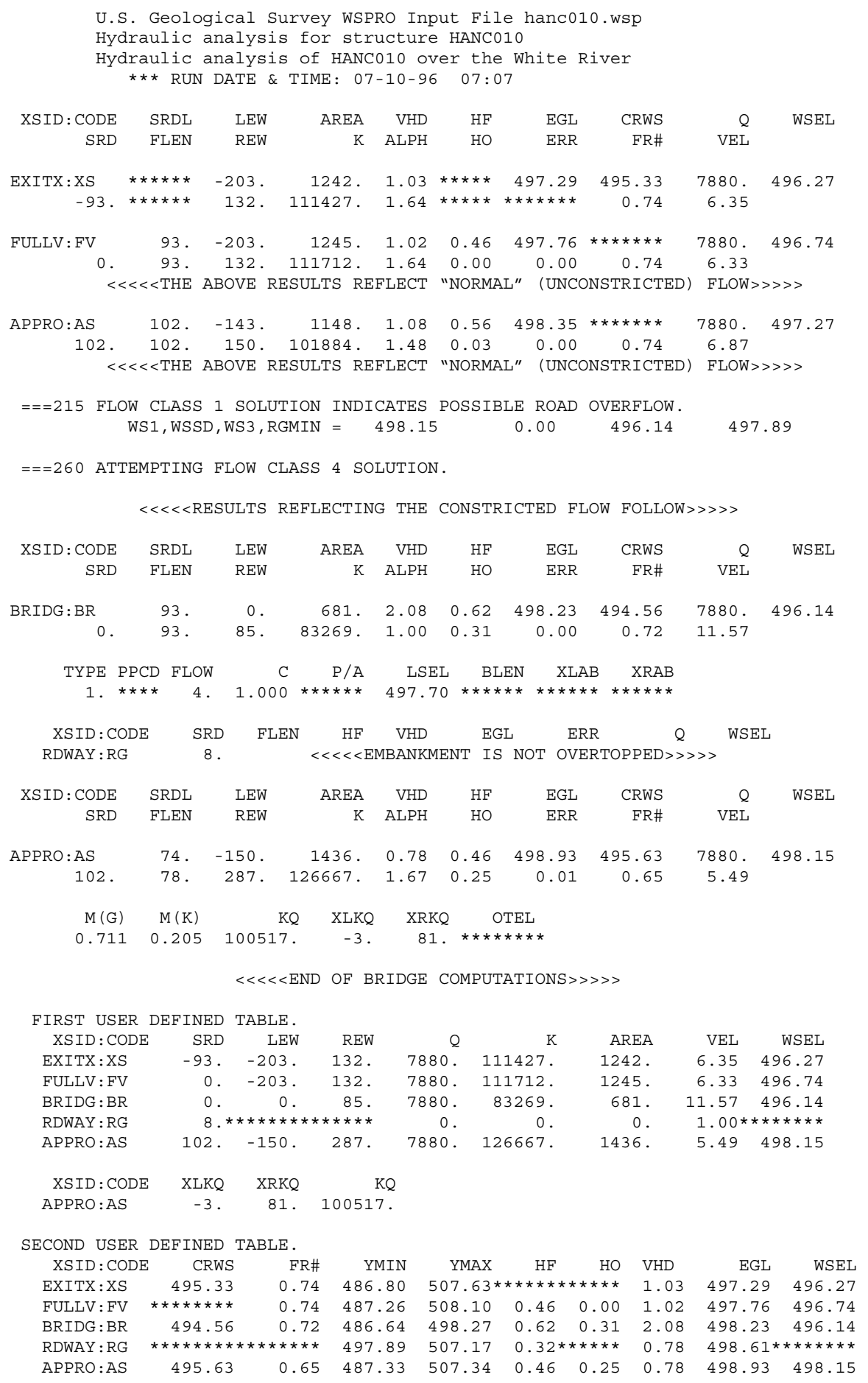




\section{APPENDIX C:}

\section{BED-MATERIAL PARTICAL-SIZE DISTRIBUTION}




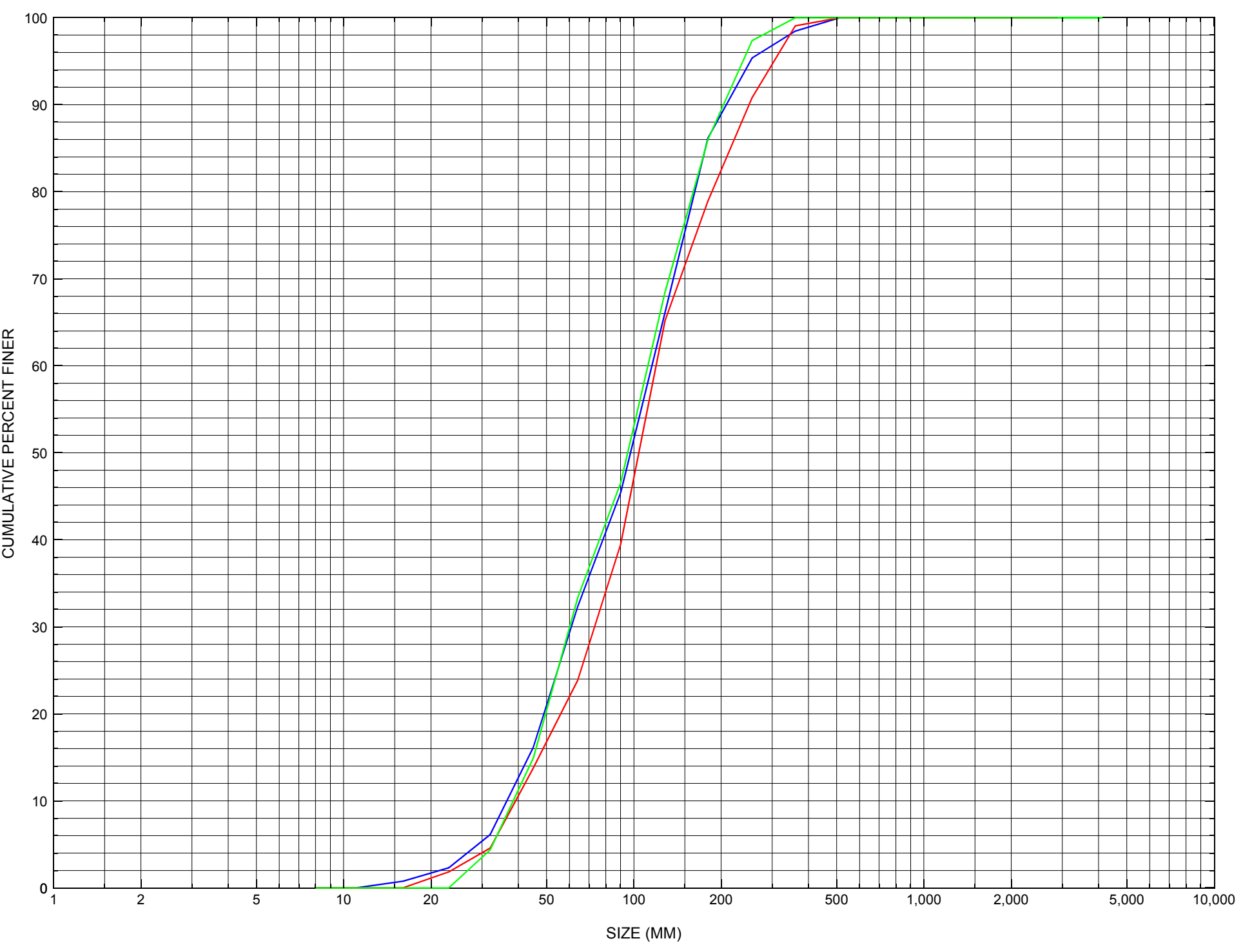

Appendix C. Bed material particle-size distributions for three pebble count transects at the approach cross-section for structure HANCTH00010010, in Hancock, Vermont. 


\section{APPENDIX D: \\ HISTORICAL DATA FORM}




\section{Structure Number HANCTH0010010}

\section{General Location Descriptive}

Data collected by (First Initial, Full last name) M. IVANOFF

Date $(M M / D D / Y Y) \_\mathbf{0 8} / \underline{\mathbf{2 6}} / \underline{\mathbf{9 4}}$

Highway District Number (I - 2; nn) 04

Town (FIPS place code; I - 4; nnnnn) $\mathbf{3 1 5 2 5}$

Waterway (I - 6) WHITE RIVER

Route Number TH010

Topographic Map Hancock

Latitude (I - 16; nnnn.n) $\mathbf{4 3 5 5 2}$
County (FIPS county code; I - 3; nnn)

Mile marker (I - 11; nnn.nnn) $\mathbf{0 0 0 0 0 0}$

Road Name (I - 7): -

Vicinity (I - 9) 0.01 MI TO JCT W VT100

Hydrologic Unit Code: $\mathbf{0 1 0 8 0 1 0 5}$

Longitude (i - 17; nnnnn.n) $\mathbf{7 2 5 0 4}$

\section{Select Federal Inventory Codes}

FHWA Structure Number (I - 8) $\mathbf{1 0 0 1 0 8 0 0 1 0 0 1 0 8}$

Maintenance responsibility $(I-21 ; n n) \quad \mathbf{0 3}$

Year built (I - 27; YYYY) 1939

Average daily traffic, ADT (I - 29; nnnnnn) 000200

Year of ADT (I - 30; YY) $\mathbf{9 0}$

Opening skew to Roadway $(I-34 ; n n) \quad \mathbf{0 0}$

Operational status $(I-41 ; X) \underline{\mathbf{A}}$

Structure type (I - 43; nnn) $\mathbf{3 0 2}$

Approach span structure type (I - 44; nnn) $\mathbf{0 0 0}$

Number of spans (I - 45; nnn) $\mathbf{0 0 1}$

Number of approach spans (I - 46; nnnn) $\mathbf{0 0 0 0}$

Comments:

Structural report of 7/1/94 indicates that the concrete curtain walls have random stains and previous spalls have been patched. Cracks have been sealed with caulking. The downstream end of the right abutment and its downstream wingwall have a newer concrete facing. The left abutment has a newer concrete subfooting protected with stone fill. The waterway has a slight turn into the structure. Erosion not addressed. Settlement has possibly created the old cracks which now seems stabilized. No channel scour or drift/vegetation. Paved road approaches with no wash reported. 


\section{Bridge Hydrologic Data}

Is there hydrologic data available? $\underline{\mathbf{N}}$ if No, type ctrl-n $h \quad$ VTAOT Drainage area $\left(m i^{2}\right)$ : -

Terrain character:

Stream character \& type: -

Streambed material: STONE AND GRAVEL

Discharge Data (cfs): $\quad \mathrm{Q}_{2.33}$

$$
\mathrm{Q}_{50}
$$

Record flood date $(M M / D D / Y Y):-$

$$
\begin{array}{ll}
Q_{10} \_- & Q_{25} \ldots \\
Q_{100 \_-} & Q_{500}-
\end{array}
$$

Water surface elevation $(f t):-$

Estimated Discharge (cfs): Velocity at $\mathrm{Q}-$ $(\mathrm{ft} / \mathrm{s}):$

Ice conditions (Heavy, Moderate, Light) : -

Debris (Heavy, Moderate, Light):

The stage increases to maximum highwater elevation (Rapidly, Not rapidly):

The stream response is (Flashy, Not flashy):

Describe any significant site conditions upstream or downstream that may influence the stream's stage: -

Watershed storage area (in percent): - _ \%

The watershed storage area is: - (1-mainly at the headwaters; 2- uniformly distributed; 3-immediatly upstream oi the site)

Water Surface Elevation Estimates for Existing Structure:

\begin{tabular}{|l|l|l|l|l|l|}
\hline Peak discharge frequency & $Q_{2.33}$ & $Q_{10}$ & $Q_{25}$ & $Q_{50}$ & $Q_{100}$ \\
Water surface elevation (ft)) & - & - & - & - & - \\
Velocity (ft/sec) & - & - & - & - & - \\
\hline
\end{tabular}

Long term stream bed changes: -

Is the roadway overtopped below the $\mathrm{Q}_{100}$ ? (Yes, No, Unknown): $\mathbf{U} \quad$ Frequency: Relief Elevation $(f t)$ :

Discharge over roadway at $Q_{100}\left(f^{3} / \mathrm{sec}\right)$ :

Are there other structures nearby? (Yes, No, Unknown): Upstream distance (miles): Town: If No or Unknown, type ctrl-n os Highway No. : Structure No. : -Year Built:

Clear span (ft): Clear Height (ft): Full Waterway $\left(f t^{2}\right)$ : 
Downstream distance (miles): Town: Year Built:

Highway No. : Structure No. : Structure Type:

Clear span (ft): Clear Height $(f t)$ : Full Waterway $\left(f t^{2}\right)$ :

Comments:

\section{USGS Watershed Data}

Watershed Hydrographic Data

Drainage area $(D A) \stackrel{59.81}{\mathrm{mi}^{2}}$ Lake and pond area $\mathbf{0 . 0 4}$ $\mathrm{mi}^{2}$

Watershed storage (ST) 0.1

Bridge site elevation 880 Main channel length 10.54 $\mathrm{ft}$ $\%$ $10 \%$ channel length elevation $\mathbf{9 0 0}$ $\mathrm{ft} \quad 85 \%$ channel length elevation $\mathrm{ft}$

Main channel slope $(S)$

(S) 131.56 $\mathrm{ft} / \mathrm{mi}$

Watershed Precipitation Data

Average site precipitation in Average headwater precipitation in

Maximum 2yr-24hr precipitation event $(124,2)$ in

Average seasonal snowfall (Sn) $\mathrm{ft}$ 


\section{Bridge Plan Data}

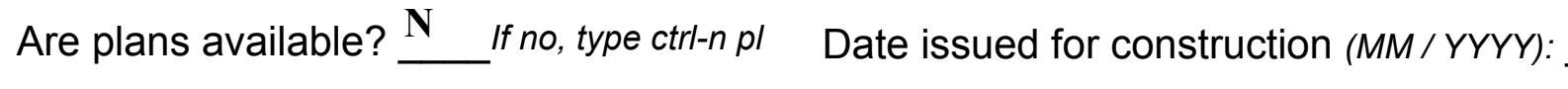

Project Number

Minimum channel bed elevation:

Low superstructure elevation: USLAB DSLAB USRAB DSRAB Benchmark location description:

NO BENCHMARK INFORMATION

Reference Point (MSL, Arbitrary, Other): Datum (NAD27, NAD83, Other):

Foundation Type: 4

If 1: Footing Thickness

If 2: Pile Type: (1-Wood; 2-Steel or metal; 3-Concrete)

If 3 : Footing bottom elevation:

Is boring information available? $\mathbf{N}$ If no, type ctrl-n bi Number of borings taken:

Foundation Material Type: $\mathbf{3}$ (1-regolith, 2-bedrock, 3-unknown)

Briefly describe material at foundation bottom elevation or around piles:

NO FOUNDATION MATERIAL INFORMATION

Comments:

NO PLANS. 


\section{Cross-sectional Data}

Is cross-sectional data available? $\mathbf{N}$ If no, type ctrl-n xs

Source (FEMA, VTAOT, Other)? -

Comments: NO CROSS SECTION INFORMATION

\begin{tabular}{|l|l|l|l|l|l|l|l|l|l|l|l|}
\hline Station & - & - & - & - & - & - & - & - & - & - & - \\
\hline Feature & - & - & - & - & - & - & - & - & - & - & - \\
\hline $\begin{array}{l}\text { Low cord } \\
\text { elevation }\end{array}$ & - & - & - & - & - & - & - & - & - & - & - \\
\hline $\begin{array}{l}\text { Bed } \\
\text { elevation }\end{array}$ & - & - & - & - & - & - & - & - & - & - & - \\
\hline $\begin{array}{l}\text { Low cord to } \\
\text { bed length }\end{array}$ & - & - & - & - & - & - & - & - & - & - & - \\
\hline Station & - & - & - & - & - & - & - & - & - & - & - \\
\hline Feature & - & - & - & - & - & - & - & - & - & - & - \\
\hline $\begin{array}{l}\text { Low cord } \\
\text { elevation }\end{array}$ & - & - & - & - & - & - & - & - & - & - & - \\
\hline $\begin{array}{l}\text { Bed } \\
\text { elevation }\end{array}$ & - & - & - & - & - & - & - & - & - & - & - \\
\hline $\begin{array}{l}\text { Low cord to } \\
\text { bed length }\end{array}$ & - & - & - & - & - & - & - & - & - & - & - \\
\hline
\end{tabular}

Source (FEMA, VTAOT, Other)?

Comments: NO CROSS SECTION INFORMATION

\begin{tabular}{|l|l|l|l|l|l|l|l|l|l|l|l|}
\hline Station & - & - & - & - & - & - & - & - & - & - & - \\
\hline Feature & - & - & - & - & - & - & - & - & - & - & - \\
\hline $\begin{array}{l}\text { Low cord } \\
\text { elevation }\end{array}$ & - & - & - & - & - & - & - & - & - & - & - \\
\hline $\begin{array}{l}\text { Bed } \\
\text { elevation }\end{array}$ & - & - & - & - & - & - & - & - & - & - & - \\
\hline $\begin{array}{l}\text { Low cord to } \\
\text { bed length }\end{array}$ & - & - & - & - & - & - & - & - & - & - & - \\
\hline Station & - & - & - & - & - & - & - & - & - & - & - \\
\hline Feature & - & - & - & - & - & - & - & - & - & - & - \\
\hline $\begin{array}{l}\text { Low cord } \\
\text { elevation }\end{array}$ & - & - & - & - & - & - & - & - & - & - & - \\
\hline $\begin{array}{l}\text { Bed } \\
\text { elevation }\end{array}$ & - & - & - & - & - & - & - & - & - & - & - \\
\hline $\begin{array}{l}\text { Low cord to } \\
\text { bed length }\end{array}$ & - & - & - & - & - & - & - & - & - & - & - \\
\hline
\end{tabular}




\section{APPENDIX E: \\ LEVEL I DATA FORM}


U. S. Geological Survey

Bridge Field Data Collection and Processing Form

Qa/Qc Check by: MAW Date: 2/7/95

\section{A. General Location Descriptive}

1. Data collected by (First Initial, Full last name) M. IVANOFF

2. Highway District Number $\mathbf{0 4}$

Mile marker $\mathbf{0}$

County ADDISON (001)

Town HANCOCK (31525)

Waterway (I - 6) WHITE RIVER

Road Name CHURCHVILLE

Route Number TH001

Hydrologic Unit Code: $\mathbf{0 1 0 8 0 1 0 5}$

3. Descriptive comments:

Located 0.01 mile from the junction of Town Highway 1 with VT 100.

\section{B. Bridge Deck Observations}
4. Surface cover... LBUS 4
RBUS 4
LBDS 4
RBDS 4
Overall 4

(2b us, ds,lb,rb: 1- Urban; 2- Suburban; 3- Row crops; 4- Pasture; 5- Shrub- and brushland; 6- Forest; 7- Wetland)
5. Ambient water surface...US $\underline{2}$
UB 1
DS 1
(1- pool; 2- riffle)

6. Bridge structure type 1 (1- single span; 2- multiple span; 3- single arch; 4- multiple arch; 5-cylindrical culvert; 6- box culvert; or 7- other)
7. Bridge length 91
(feet)
Span length $\mathbf{8 9}$
(feet)
Bridge width 19.3 (feet)

\section{Road approach to bridge:}
8. LB 1 RB 1
( 0 even, 1- lower, 2- higher)
9. LB 1
RB 1
(1- Paved, 2- Not paved)

10. Embankment slope (run / rise in feet / foot)

$$
\text { US left }
$$

2.4:1

US right

3.8:1

\begin{tabular}{|c|c|c|c|c|}
\hline & \multicolumn{2}{|c|}{ Protection } & \multirow{2}{*}{ 13. Erosion } & \multirow{2}{*}{ 14.Severity } \\
\hline & 11.Type & 12.Cond. & & \\
\hline LBUS & 2 & 1 & 2 & 1 \\
\hline RBUS & $\mathbf{0}$ & - & $\mathbf{0}$ & $\mathbf{0}$ \\
\hline RBDS & $\mathbf{0}$ & - & $\mathbf{0}$ & $\mathbf{0}$ \\
\hline LBDS & 2 & 2 & 2 & 2 \\
\hline
\end{tabular}

Bank protection types: 0- none; 1- < 12 inches;

$$
\text { 2- < } 36 \text { inches; } 3 \text { - < } 48 \text { inches; }
$$

4- < 60 inches; 5- wall / artificial levee

Bank protection conditions: 1- good; 2- slumped;

3- eroded; 4- failed

Erosion: 0 - none; 1- channel erosion; 2-

road wash; 3- both; 4- other

Erosion Severity: 0 - none; 1- slight; 2- moderate; 3- severe

\section{Channel approach to bridge (BF):}

15. Angle of approach: $1 \mathbf{1 0}$

16. Bridge skew: 15

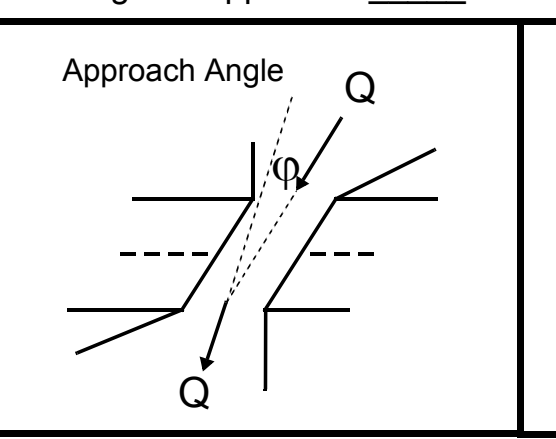

17. Channel impact zone 1:

Where? RB (LB, RB)

Exist? $\mathbf{Y}(Y$ or $N)$ Bridge Skew Angle

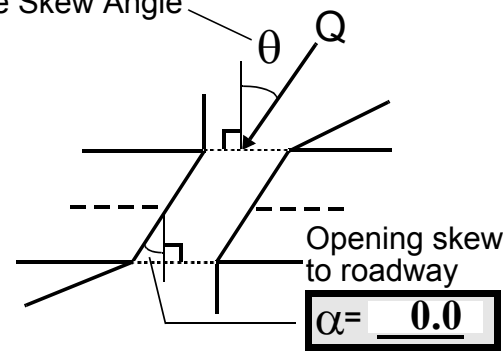

Range? 15 feet DS

Severity $\mathbf{0}$

Channel impact zone 2:

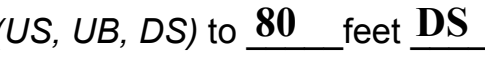

Where? LB (LB, RB)

Exist? $\mathbf{Y}(Y$ or $N)$

Range? $\underline{\mathbf{2 5 0}}$ feet $\underline{\mathbf{U S}}$ (US, UB, DS) to $\underline{\mathbf{2 0 0}}$ feet $\underline{\mathbf{U S}}$

Impact Severity: 0- none to very slight; 1- Slight; 2- Moderate; 3- Severe 
18. Bridge Type: 1a

1a- Vertical abutments with wingwalls

1 b- Vertical abutments without wingwalls

2- Vertical abutments and wingwalls, sloping embankment Wingwalls perpendicular to abut. face

3- Spill through abutments

4- Sloping embankment, vertical wingwalls and abutments

Wingwall angle less than $90^{\circ}$.

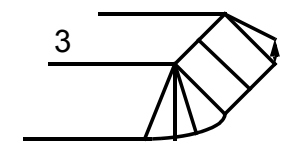

\section{.}

19. Bridge Deck Comments (surface cover variations, measured bridge and span lengths, bridge type variations, approach overflow width, etc.)

4. Banks are lined with trees but pasture and suburban conditions exist beyond.

7. Measured bridge length: 91, span: 89, width: 19 feet.

18. 1a type bridge to a depth of $6 \mathrm{ft}$. then a type 4 bridge above.

\section{Upstream Channel Assessment}

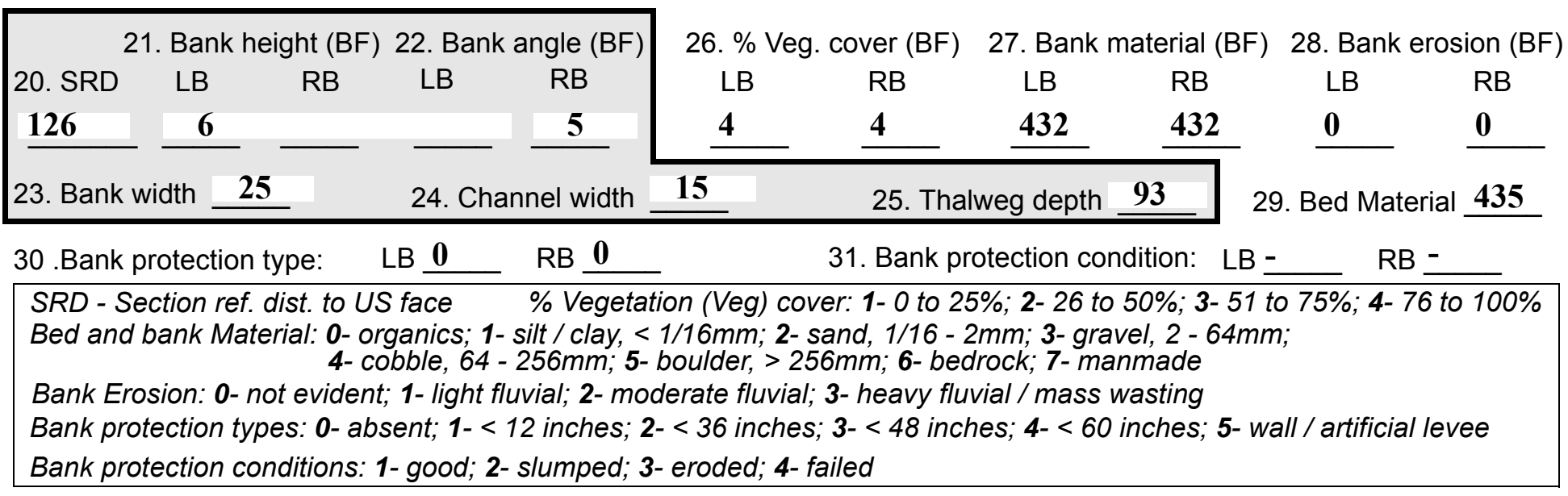

32. Comments (bank material variation, minor inflows, protection extent, etc.):

27. Bank material is cobble with gravel and sand.

29. Bed material is cobble with gravel and some boulders.

A silty muck overlies the banks about 2 - 3 inches deep. 
36. Point bar extent: 140 feet $\underline{\mathbf{U S}}$ (US, UB) to $\underline{\mathbf{3 0 0}}$ feet $\underline{\mathrm{US}}$ (US, UB, DS) positioned $\underline{\mathbf{7 0}} \%$ LB to $\underline{\mathbf{1 0 0}} \%$ RB

37. Material: $\mathbf{4 3 2}$

38. Point or side bar comments (Circle Point or Side; Note additional bars, material variation, status, etc.):

Material is cobble with gravel and sand. Resembles a side bar within the channel.

39. Is a cut-bank present? $\mathbf{N}$ ( $Y$ or if $N$ type ctrl-n $c b)$

40. Where? - $(L B$ or $R B)$

41. Mid-bank distance: -

42. Cut bank extent: -

feet -

(US, UB) to feet (US, UB, DS)

43. Bank damage: -

(1- eroded and/or creep; 2- slip failure; 3- block failure)

44. Cut bank comments (eg. additional cut banks, protection condition, etc.):

NO CUT BANKS

\section{Is channel scour present? $\mathbf{Y}$ ( $Y$ or if $N$ type ctrl-n cs) 46. Mid-scour distance: 0 US}
47. Scour dimensions: Length $\underline{\mathbf{4 0}}$
Width 12
Depth : 1.2
Position 5
$\%$ LB to $\underline{\mathbf{3 0}} \% \mathrm{RB}$

48. Scour comments (eg. additional scour areas, local scouring process, etc.):

Localized scour due to bridge constriction of the channel. Stone fill is in place along the left abutment providing protection for the exposed left abutment footing.

49. Are there major confluences? $\mathbf{N}$

51. Confluence 1: Distance -

Confluence 2: Distance -

Confluence 2. Distance

54. Confluence comments (eg. confluence name):

NO MAJOR CONFLUENCES
( $Y$ or if $N$ type ctrl-n $m c)$

52. Enters on -

Enters on ( $L B$ or $R B)$ (LB or $R B)$
50. How many? -

53. Type(1- perennial; 2- ephemeral)

Type (1-perennial; 2- ephemeral)

\section{Under Bridge Channel Assessment}

55. Channel restraint (BF)? LB 2

\begin{tabular}{|ccccc}
\hline \multicolumn{2}{|c}{ 56. Height (BF) } & \multicolumn{3}{c}{57 Angle (BF) } \\
LB & RB & & LB & RB \\
$\mathbf{5 9}$ & & & $\mathbf{1 . 5}$ & \\
\hline
\end{tabular}
(1- natural bank; 2- abutment; 3- artificial levee)

58. Bank width (BF) 59. Channel width (Amb) -

61. Material (BF)

LB RB

$\underline{2} \quad 7$
62. Erosion (BF)

LB RB

$7 \quad 0$

Bed and bank Material: 0- organics; 1- silt / clay, < 1/16mm; 2- sand, 1/16 - 2mm; 3- gravel, 2 - 64mm; 4- cobble, 64 - 256mm; 5- boulder, > 256mm; 6- bedrock; 7- manmade

Bank Erosion: 0- not evident; 1- light fluvial; 2- moderate fluvial; 3- heavy fluvial / mass wasting

64. Comments (bank material variation, minor inflows, protection extent, etc.):

342

Right bank has an overlying muck layer about 4 inches deep covering a sand bank with some cobble within the material leading up to the abutment.

63. Bed material is gravel with cobble and some sand. 
65. Debris and Ice Is there debris accumulation?

(Yor $N)$ 66. Where? $\mathbf{N}$

(1- Upstream; 2- At bridge; 3-Both)

67. Debris Potential ( 1- Low; 2- Moderate; 3- High)

68. Capture Efficiency 1 (1-Low; 2- Moderate; 3- High)

69. Is there evidence of ice build-up? 1 (Y or $N)$

Ice Blockage Potential $\mathbf{N}$

(1-Low; 2-Moderate; 3- High)

70. Debris and Ice Comments:

1

67. No debris accumulation near the bridge, upstream is laterally stable, has few cut banks, consist of cobble and boulder sized material.

68. High channel gradient and the span length is more than approximately $80 \%$ of the upstream bank width.

\begin{tabular}{|l|c|c|c|c|c|c|c|c|}
\hline Abutments & $\begin{array}{c}\text { 71. Attack } \\
\angle \text { (BF) }\end{array}$ & $\begin{array}{c}\text { 72. Slope } \angle \\
\text { (Qmax) }\end{array}$ & $\begin{array}{c}\text { 73. Toe } \\
\text { loc. (BF) }\end{array}$ & $\begin{array}{c}\text { 74. Scour } \\
\text { Condition }\end{array}$ & $\begin{array}{c}75 . \text { Scour } \\
\text { depth }\end{array}$ & $\begin{array}{c}\text { 76. Exposure } \\
\text { depth }\end{array}$ & 77. Material & 78. Length \\
\hline LABUT & & $\mathbf{0}$ & $\mathbf{9 0}$ & $\mathbf{2}$ & $\mathbf{2}$ & $\mathbf{0}$ & $\mathbf{1}$ & $\mathbf{9 0}$ \\
\hline RABUT & $\mathbf{1}$ & $\mathbf{1 5}$ & $\mathbf{9 0}$ & & & $\mathbf{2}$ & $\mathbf{0}$ & $\mathbf{8 5}$ \\
\hline
\end{tabular}

Pushed: $L B$ or RB

Toe Location (Loc.): 0- even, 1- set back, 2- protrudes

Scour cond.: 0- not evident; 1- evident (comment); 2- footing exposed; 3-undermined footing; 4- piling exposed; 5- settled; 6- failed

Materials: 1- Concrete; 2- Stone masonry or drywall; 3- steel or metal; 4- wood

79. Abutment comments (eg. undermined penetration, unusual scour processes, debris, etc.):

80. Wingwalls:

Exist? Material? Scour Scour Exposure $\begin{aligned} & 81 . \\ & \text { Angle? Length? }\end{aligned}$ Condition? depth? depth?

USLWW:

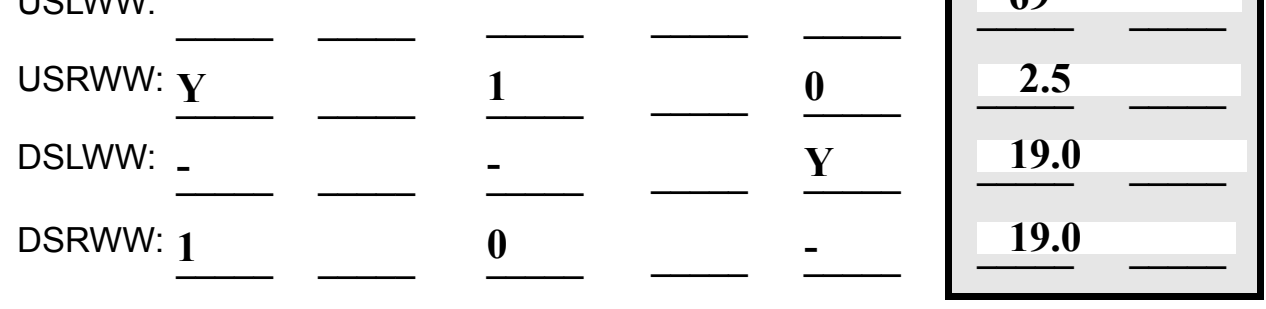

Wingwall materials: 1- Concrete; 2- Stone masonry or drywall; 3- steel or metal; 4- wood

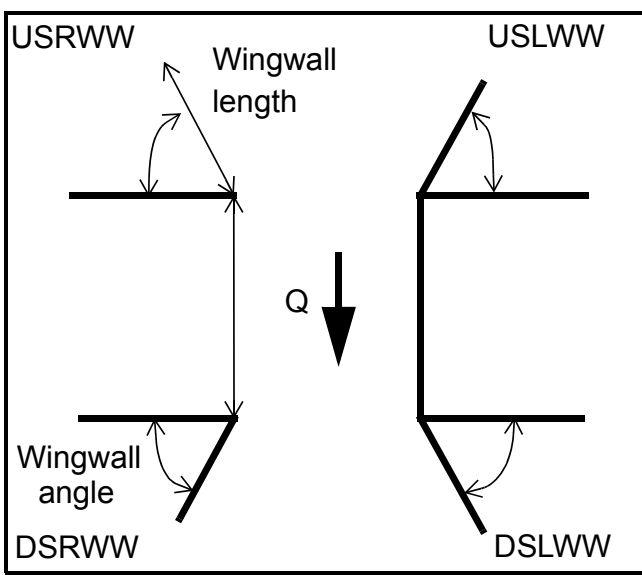

82. Bank / Bridge Protection:

\begin{tabular}{|l|l|l|l|l|l|l|l|l|}
\hline Location & USLWW & USRWW & LABUT & RABUT & LB & RB & DSLWW & DSRWW \\
\hline Type & - & $\mathbf{0}$ & $\mathbf{Y}$ & - & $\mathbf{1}$ & - & $\mathbf{1}$ & - \\
\hline Condition & $\mathbf{Y}$ & - & $\mathbf{1}$ & - & $\mathbf{1}$ & - & $\mathbf{1}$ & - \\
\hline Extent & $\mathbf{1}$ & - & $\mathbf{0}$ & $\mathbf{2}$ & $\mathbf{0}$ & $\mathbf{2}$ & $\mathbf{0}$ & - \\
\hline
\end{tabular}

Bank / Bridge protection types: 0- absent; 1- < 12 inches; 2- < 36 inches; 3- < 48 inches; 4- < 60 inches; 
83. Wingwall and protection comments (eg. undermined penetration, unusual scour processes, etc.):

-
-
-
-
-
1
1
1
0
-
-

\section{Piers:}

84. Are there piers? _ (Y or if $N$ type ctrl-n pr)

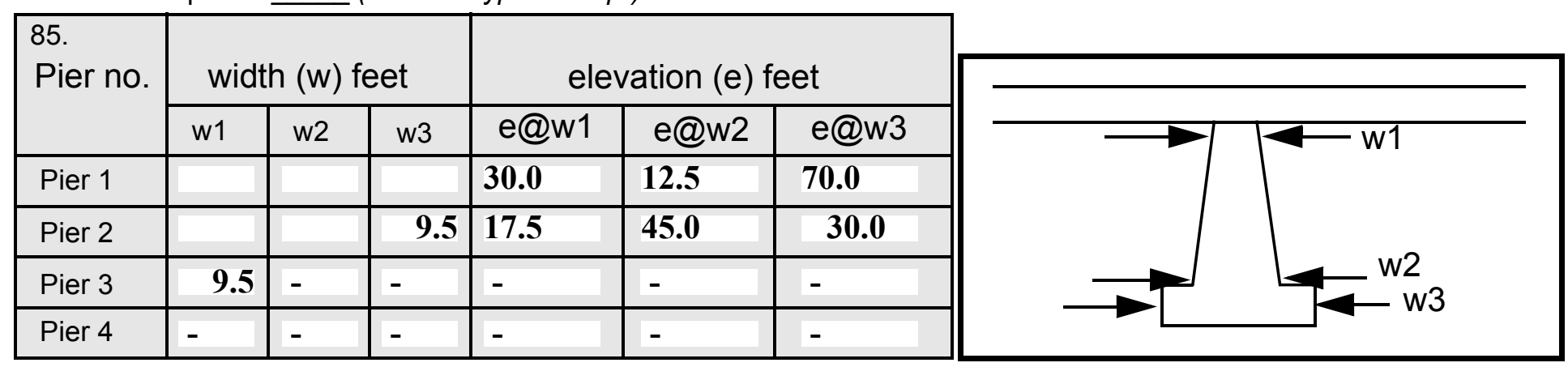

\begin{tabular}{|c|c|c|c|c|}
\hline Level 1 Pier Descr. & 1 & 2 & 3 & 4 \\
\hline 86. Location (BF) & & - & - & - \\
\hline 87. Type & & - & - & - \\
\hline 88. Material & & - & - & - \\
\hline 89. Shape & & - & - & - \\
\hline 90. Inclined? & & - & - & - \\
\hline 91. Attack $\angle(B F)$ & & - & - & - \\
\hline 92. Pushed & & - & - & - \\
\hline 93. Length (feet) & - & - & - & - \\
\hline 94. \# of piles & & - & - & - \\
\hline 95. Cross-members & & - & - & - \\
\hline 96. Scour Condition & & - & - & - \\
\hline 97. Scour depth & $\mathbf{N}$ & - & - & - \\
\hline 98. Exposure depth & - & - & - & - \\
\hline
\end{tabular}

LFP, LTB, LB, MCL, MCM, MCR, RB, RTB, RFP

1- Solid pier, 2- column, 3- bent

1-Wood; 2- concrete; 3- metal; 4- stone

1- Round; 2- Square; 3- Pointed

Y-yes; $N$ - no

$L B$ or $R B$

0- none; 1- laterals; 2- diagonals; 3- both

0- not evident; 1- evident (comment);

2- footing exposed; 3- piling exposed;

4- undermined footing; 5- settled; 6- failed 
99. Pier comments (eg. undermined penetration, protection and protection extent, unusual scour processes, etc.):

-

100.

\section{E. Downstream Channel Assessment}

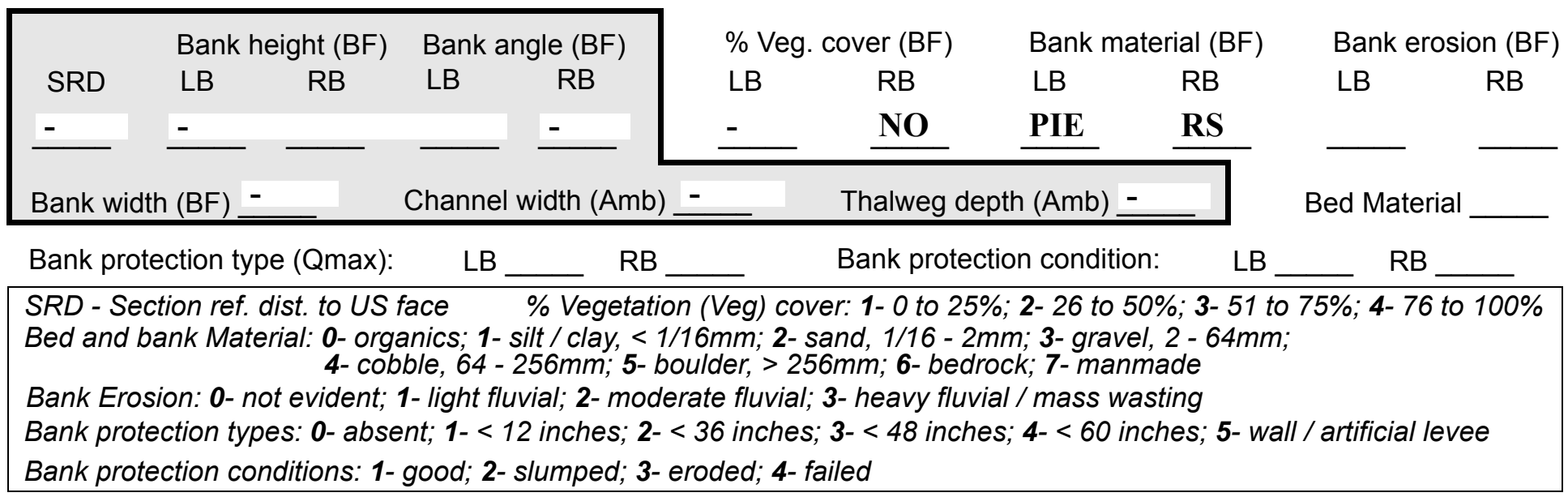

Comments (eg. bank material variation, minor inflows, protection extent, etc.):

3
4
342
432
0
0
$\mathbf{3 4 2}$
$\mathbf{0}$
$\mathbf{0}$
-
-

Some remains of concrete blocks are scattered on both the left and right banks just downstream of the bridge providing very little protection.

101. Is a drop structure present? Le (Y or $N$, if $N$ type ctrl-n ds) 102. Distance: __ feet
103. Drop: - feet
104. Structure material: $\mathbf{f t}$
(1- steel sheet pile; 2- wood pile; 3-concrete; 4- other)

105. Drop structure comments (eg. downstream scour depth):

bank material is gravel with cobble and some sand.

Right bank material is cobble with gravel and some sand.

Bed material is gravel with cobbles and some sand. 
106. Point/Side bar present? (Y or $N$. if $N$ type ctrl-n pb)Mid-bar distance:

Mid-bar width:

Point bar extent: feet

(US, UB, DS) to feet (US, UB, DS) positioned $\underline{\mathbf{N}}$ $\%$ LB to $\% R B$ Material: $\mathbf{N O}$

Point or side bar comments (Circle Point or Side; note additional bars, material variation, status, etc.):

\section{DROP STRUCTURE}

Is a cut-bank present? (Y or if $N$ type ctrl- $n$ cb) Where? (LB or $R B)$

Mid-bank distance: $\underline{\mathbf{Y}}$ Cut bank extent: $\underline{400}$ feet $\underline{150}$ (US, UB, DS) to $\underline{150}$ feet $\underline{\text { DS }}$ (US, UB, DS)

Bank damage: 600 (1- eroded and/or creep; 2- slip failure; 3- block failure)

Cut bank comments (eg. additional cut banks, protection condition, etc.):

DS

0

95

432

$\underline{\text { Is channel scour present? }}$ Ma (Y or if N type ctrl- $n$ cs) Mid-scour distance: terial Scour dimensions: Length is Width pre- Depth: $\underline{\text { dom }} \quad$ Positioned ina \%LB to ntly \%RB Scour comments (eg. additional scour areas, local scouring process, etc.): cobble with gravel and some sand.

Are there major confluences? $\mathbf{Y}$ ( $Y$ or if $N$ type ctrl-n $m c$ )

Confluence 1: Distance $\mathbf{4 0 0}$

Confluence 2: Distance $\mathbf{7 0 0}$ Enters on $\underline{\mathbf{2 0 0}}$ (LB or RB)

Enters on DS ( $L B$ or RB)

Confluence comments (eg. confluence name):
How many? $\underline{\mathbf{R B}}$

Type DS (1- perennial; 2- ephemeral)

Type 1 (1-perennial; 2- ephemeral)

\section{F. Geomorphic Channel Assessment}

107. Stage of reach evolution
1- Constructed

2- Stable

3- Aggraded

4- Degraded

5- Laterally unstable

6- Vertically and laterally unstable 
108. Evolution comments (Channel evolution not considering bridge effects; See HEC-20, Figure 1 for geomorphic descriptors):

$\mathbf{N}$

$-$

$-$

$-$

$-$

$-$

NO CHANNEL SCOUR

$\mathbf{N}$ 


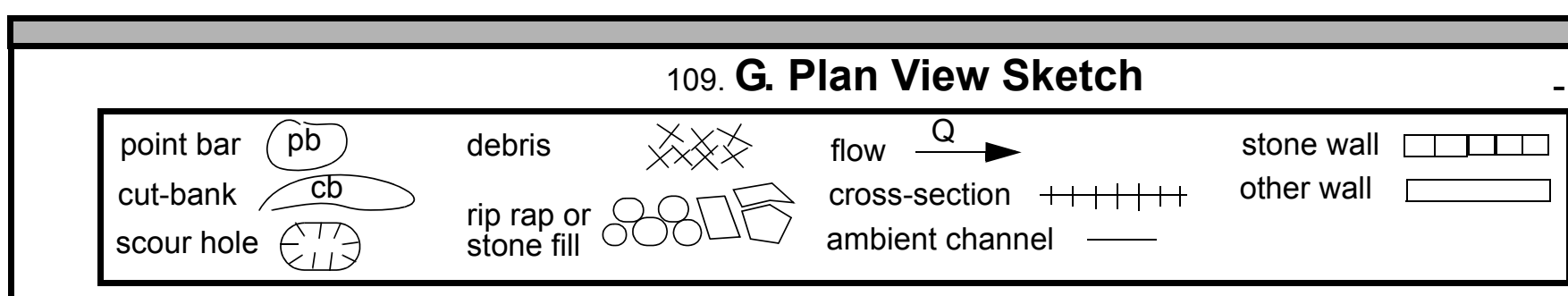


APPENDIX F:

SCOUR COMPUTATIONS 
SCOUR COMPUTATIONS

\begin{tabular}{|c|c|c|c|}
\hline $\begin{array}{ll}\text { Structure Number: HANCTH00010010 } \\
\text { Road Number: }\end{array}$ & & $\begin{array}{l}\text { Town: } \\
\text { County: }\end{array}$ & $\begin{array}{l}\text { Hancock } \\
\text { Addison }\end{array}$ \\
\hline Stream: White River & & & \\
\hline Initials SAO & Checked: & $\mathrm{EMB}$ & $7 / 22 / 96$ \\
\hline alysis of contraction scour, live & oed or $\mathrm{cl}$ & ear water & \\
\hline $\begin{array}{l}\text { Critical Velocity of Bed Material } \\
\text { Vc }=11.21 * \mathrm{y}^{\wedge} 0.1667 * \mathrm{D} 50^{\wedge} 0.33 \text { with } \mathrm{S}\end{array}$ & $\begin{array}{l}\text { converted } \\
=2.65\end{array}$ & to Engli & sh units) \\
\hline (Richardson and others, 1995, p. 2 & , eq. 16) & & \\
\hline Approach Section & & & \\
\hline Characteristic & $100 \mathrm{yr}$ & $500 \mathrm{yr}$ & other $Q$ \\
\hline Total discharge, cfs & 13000 & 19000 & 7880 \\
\hline Main Channel Area, ft2 & 1061 & 1182 & 818 \\
\hline Left overbank area, ft2 & 723 & 950 & 320 \\
\hline Right overbank area, ft2 & 1083 & 1573 & 298 \\
\hline Top width main channel, ft & 93 & 93 & 93 \\
\hline Top width L overbank, ft & 165 & 185 & 144 \\
\hline Top width $\mathrm{R}$ overbank, ft & 377 & 377 & 150 \\
\hline D50 of channel, ft & 0.325 & 0.325 & 0.325 \\
\hline D50 left overbank, ft & -- & -- & -- \\
\hline D50 right overbank, ft & -- & -- & -- \\
\hline Y1, average depth, MC, ft & 11.4 & 12.7 & 8.8 \\
\hline Y1, average depth, LOB, ft & 4.4 & 5.1 & 2.2 \\
\hline Y1, average depth, ROB, ft & 2.9 & 4.2 & 2.0 \\
\hline Total conveyance, approach & 259595 & 357058 & 126596 \\
\hline Conveyance, main channel & 157616 & 188720 & 102153 \\
\hline Conveyance, LOB & 58621 & 87720 & 15144 \\
\hline Conveyance, ROB & 43358 & 80618 & 9299 \\
\hline Percent discrepancy, conveyance & 0.0000 & 0.0000 & 0.0000 \\
\hline Qm, discharge, MC, cfs & 7893.1 & 10042.3 & 6358.5 \\
\hline Q1, discharge, LOB, Cfs & 2935.6 & 4667.8 & 942.6 \\
\hline Qr, discharge, ROB, cfs & 2171.3 & 4289.9 & 578.8 \\
\hline $\mathrm{Vm}$, mean velocity $\mathrm{MC}$, ft/s & 7.4 & 8.5 & 7.8 \\
\hline $\mathrm{Vl}$, mean velocity, LOB, ft/s & 4.1 & 4.9 & 2.9 \\
\hline Vr, mean velocity, ROB, ft/s & 2.0 & 2.7 & 1.9 \\
\hline Vc-m, crit. velocity, MC, ft/s & 11.6 & 11.8 & 11.1 \\
\hline Vc-l, crit. velocity, LOB, ft/s & $\mathrm{ERR}$ & ERR & ERR \\
\hline Vc-r, crit. velocity, ROB, ft/s & $\mathrm{ERR}$ & ERR & ERR \\
\hline Results & & & \\
\hline Live-bed(1) or Clear-Water(0) Cont & action $\mathrm{Sc}$ & our? & \\
\hline Main Channel & 0 & 0 & 0 \\
\hline Left Overbank & $\mathrm{N} / \mathrm{A}$ & $\mathrm{N} / \mathrm{A}$ & $\mathrm{N} / \mathrm{A}$ \\
\hline Right Overbank & $\mathrm{N} / \mathrm{A}$ & $\mathrm{N} / \mathrm{A}$ & $\mathrm{N} / \mathrm{A}$ \\
\hline
\end{tabular}


Clear Water Contraction Scour in MAIN CHANNEL

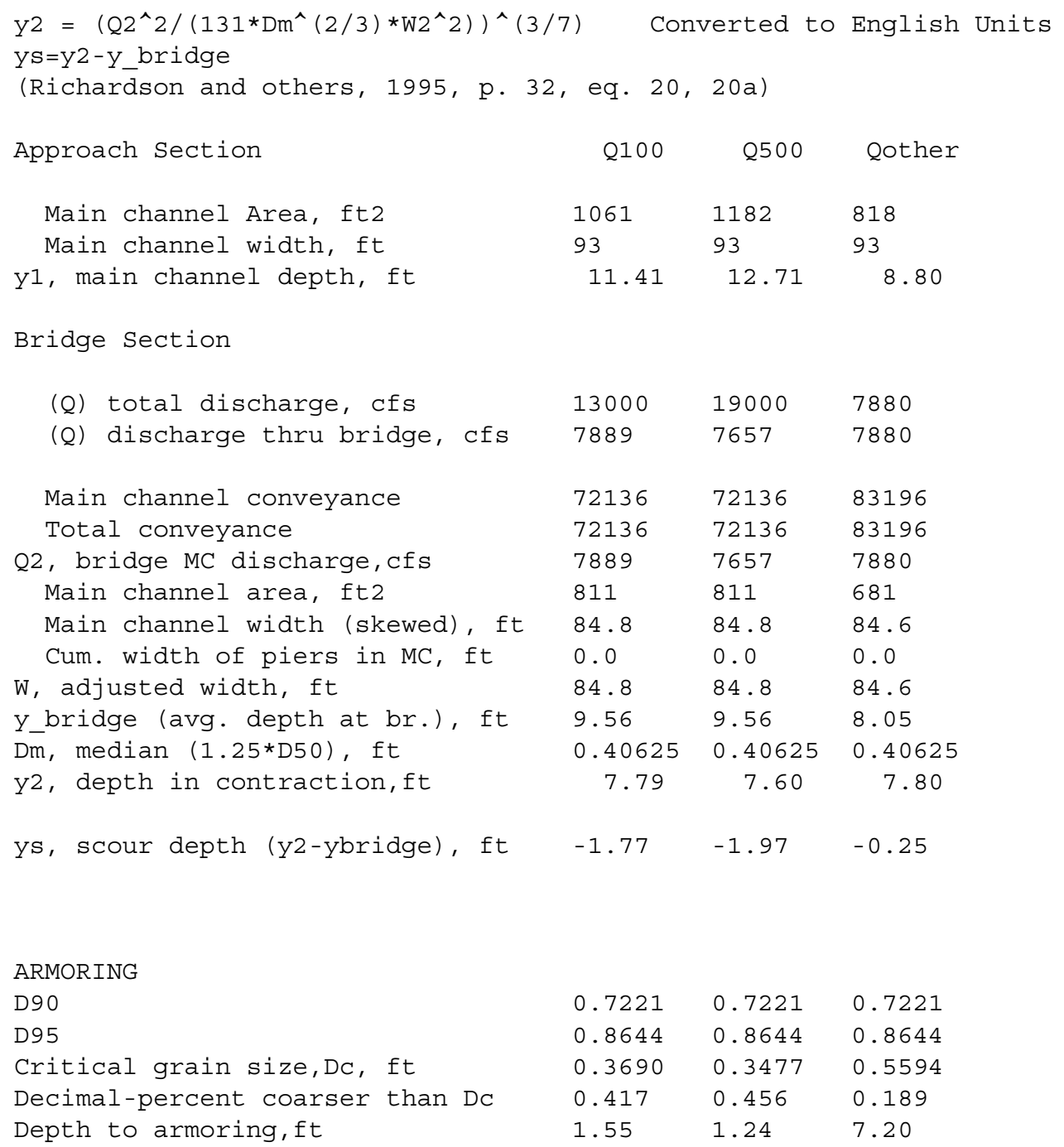


PRESSURE FLOW SCOUR COMPUTATION

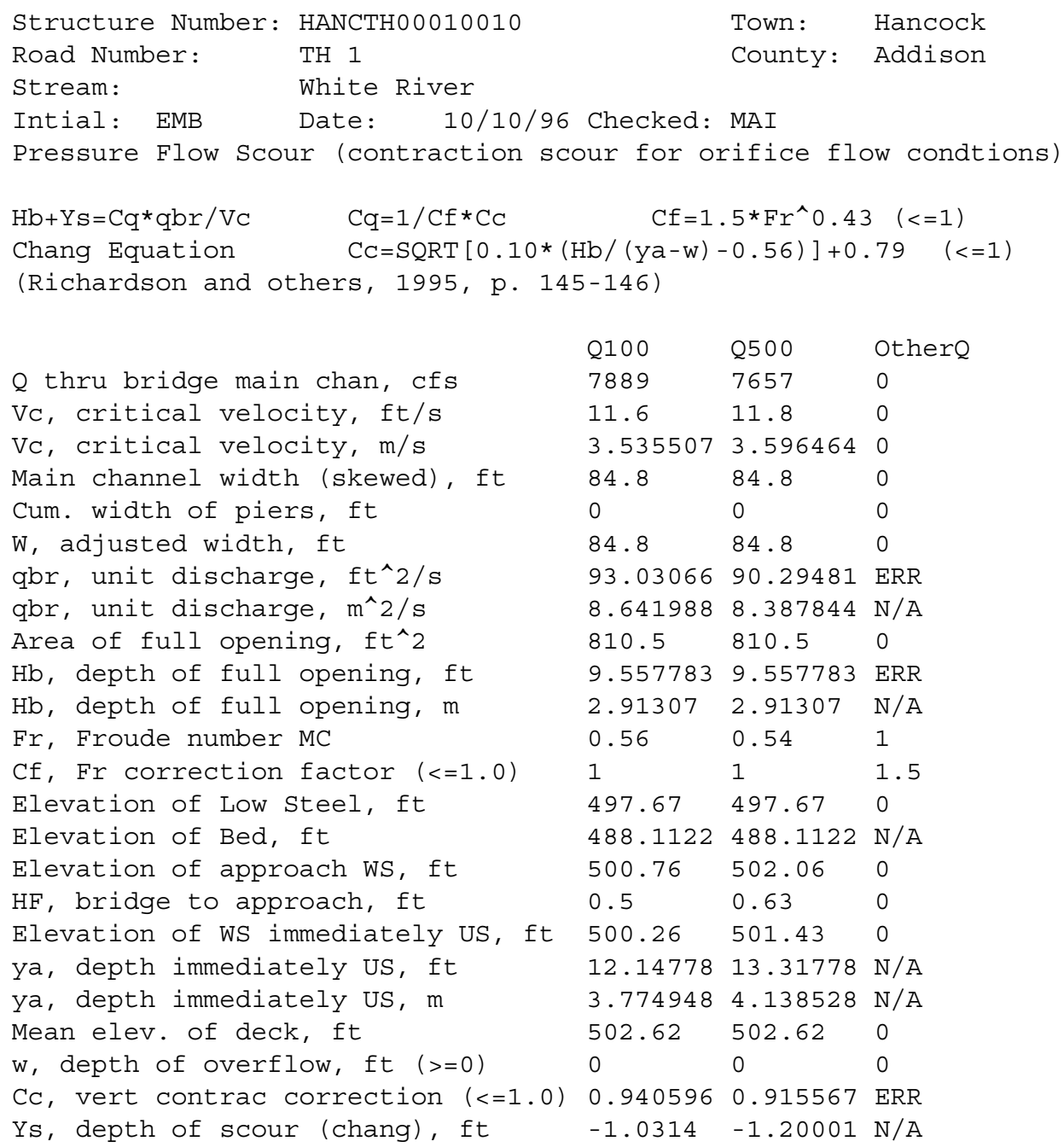




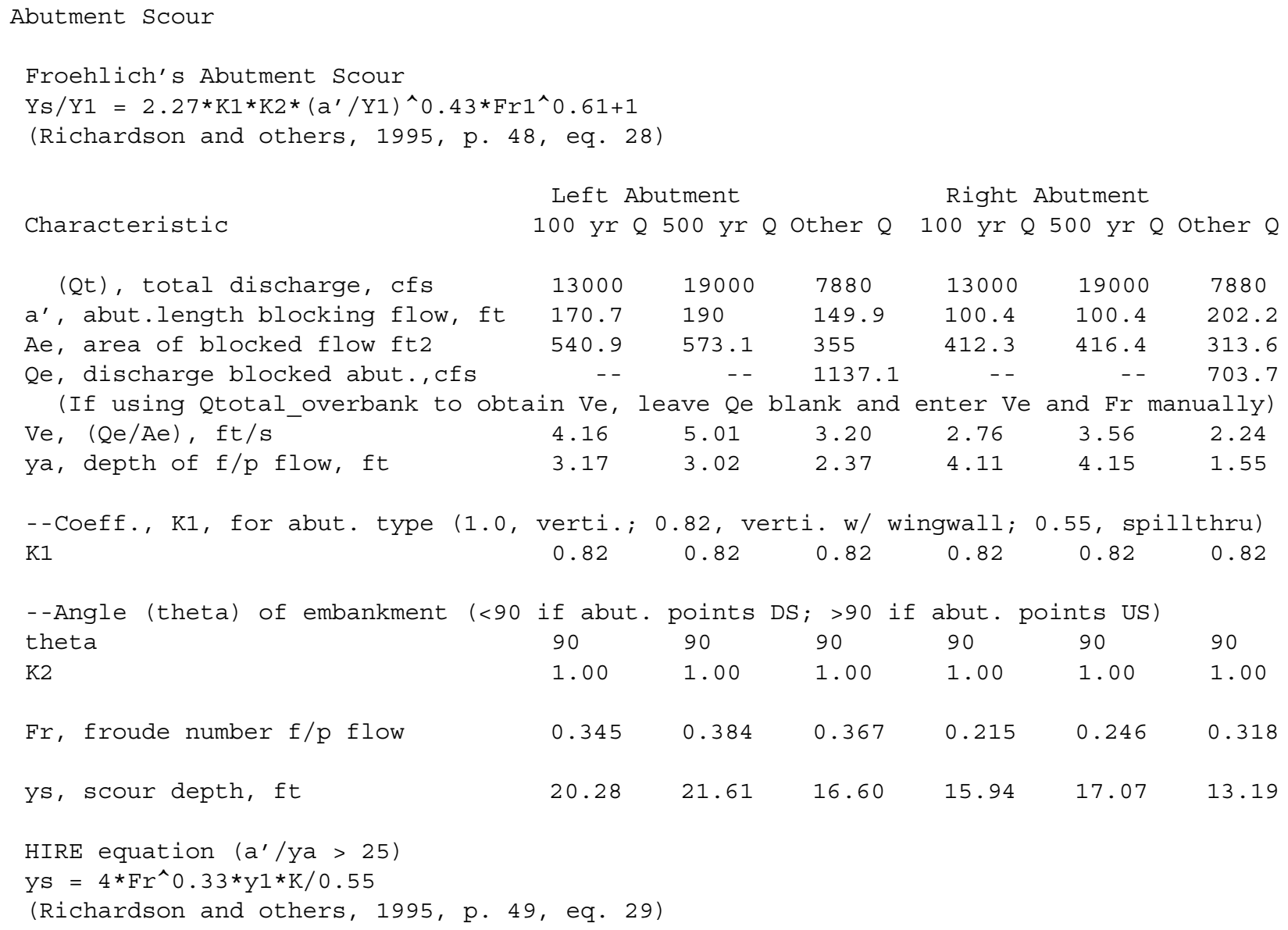




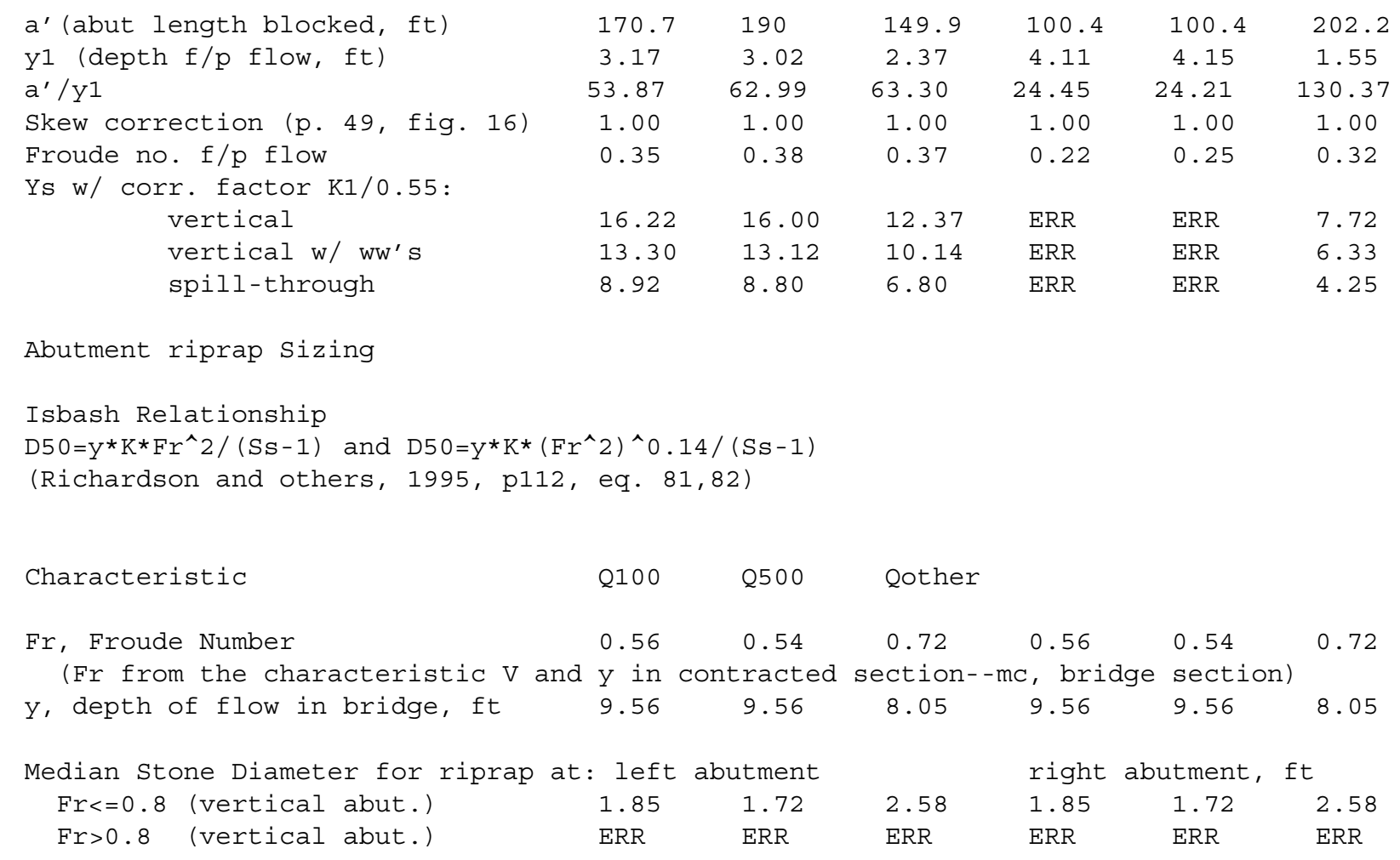

